\title{
ELECTRICAL CONDUCTIVITY OF $\mathrm{UO}_{2}$ :
}

PART II. FINAL REPORT

\section{J. LAMBERT BATES}

NOVEMBER, 1967

\section{AEC RESEARCH \& DEVELOPMENT REPORT}

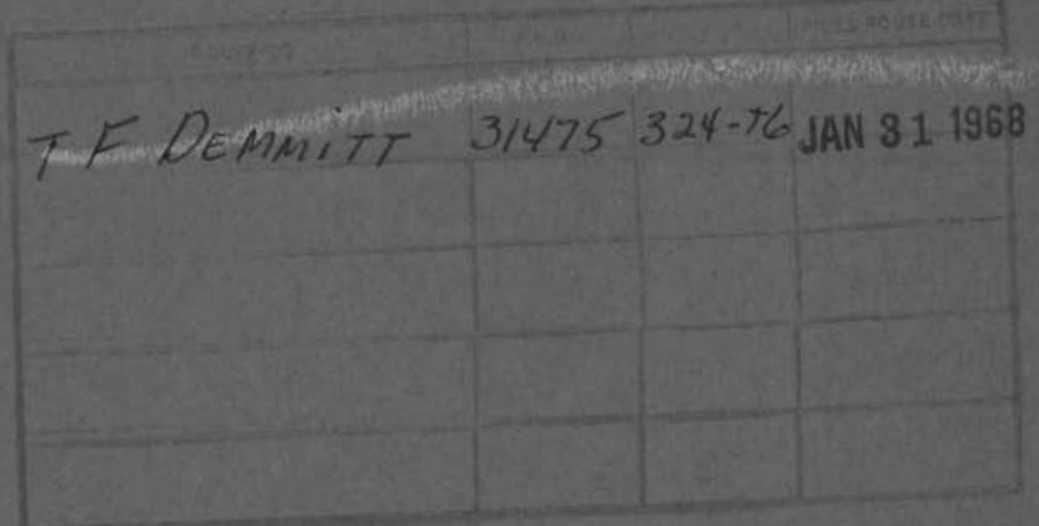

B ATTELLE B NORTHWEST 


\title{
LEGAL NOTICE
}

This report was prepared as an account of Government sponsored work. Neither the United States, nor the Commission, nor any person acting on behalf of the Commission:

A. Makes any warranty ar representation, expressed or implied, with respect to the accuracy, com. pleteness, or usefulness of the information contained in this repor, or that the use of any information, apparatus, method, or process disclosed in this report may not infringe privately owned rights; or

B. Assumes any liabilities with respect to the use of, or for damages resulting from the use of any information, apparatus, method, or process disclosed in this report.

As used in the obove, "person acting on behalf of the Commission" includes any employee or controctor of the Commission, or employee of such contractor, to the extent that such employee on con. tractor of the Commission, or emplayee of such contractor prepares, disseminates, or provides access to, any information pursuant to his employment or contract with the Commission, or his employment with such contractor

\author{
PACIFIC NORTHWEST LABORATORY \\ RICHLAND, WASHINGTON \\ operated by \\ BATTELLE MEMORIAL INSTITUTE \\ for the
}

UNITED STATES ATOMIC ENERGY COMMISSION UNDER CONTRACT AT(45-1)-1830 


\section{6}

BNWL-296 PT2

UC-25, Metals, Ceramics, and Materials

ELECTRICAL CONDUCTIVITY OF UO ${ }_{2}$ :

PART II . FINAL REPORT

By

J. Lambert Bates

Materials Research Section

Materials Department

November, 1967

FIRST IBRERTDicteD

DISTRIRLTION MADE

DEC7'67 
Printed in the United States of America Available from

Clearinghouse for Federal Scientific and Technical Information National Bureau of Standards, U.S. Department of Commerce Springfield, Virginia 22151

Price: Printed Copy $\$ 3.00 ;$ Microfiche $\$ 0.65$ 


\section{TABLE OF CONTENTS}

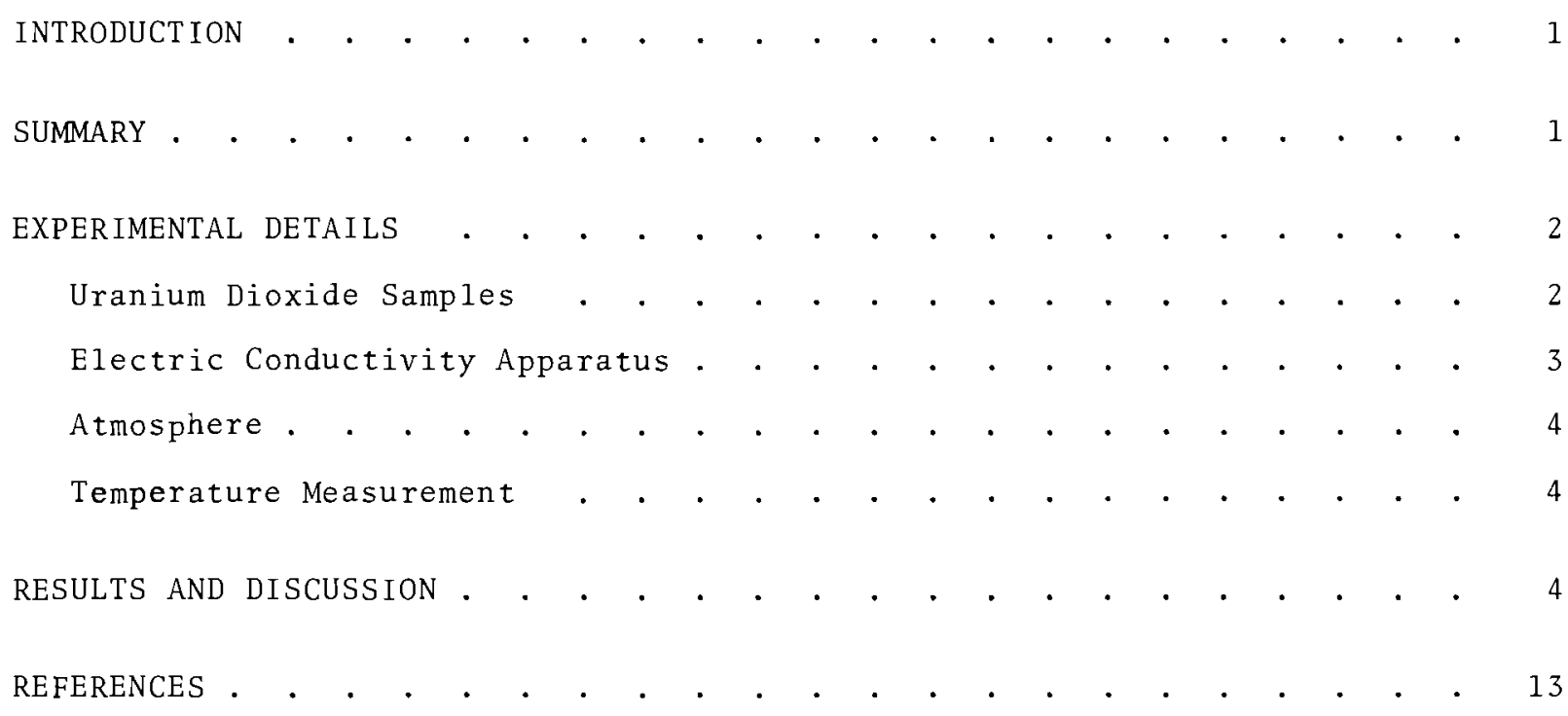

APPENDICES

A. Frequency Dependence of Electrical Conductivity of $\mathrm{UO}_{2}$. . . . . 15

B. Electrical Conductivity of $\mathrm{UO}_{2}$ ac and dc Data . . . . . . . . 18 Specimen B-40-A . . . . . . . . . . . . . . . . . . 18

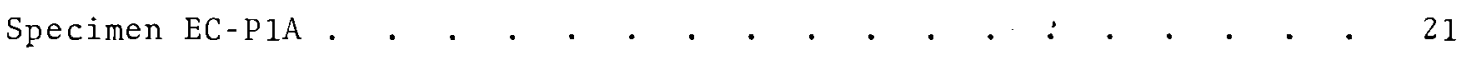

Specimen EC-P3A . . . . . . . . . . . . . . . . . . 23

Specimen B-38-C . . . . . . . . . . . . . . . . . . 23

DISTRIBUTION 


\section{LIST OF FIGURES}

1

\section{2}

3

4

5

A -1

A -2

A -3

B-1

B -2

B- 3

B -4

Schematic Representation of Four Probe, Electric Conductivity Apparatus

Schematic Representation of the Electrical

Circuit for the Four Probe, Electrical

Conductivity Apparatus

The Electrical Conductivity of Polycrystalline $\mathrm{UO}_{2}$ (B-38-C) Comparing the ac and dc Electrical Conductivity Data

The Electrical Conductivity of Polycrystalline and Single Crystal Uranium Dioxide Including Both ac and de Measurements

The Temperature Dependence of $\frac{\Delta(\ln \sigma)}{\Delta\left(T^{-1}\right)}$ for the Intrinsic Electrical Conductivity of $\mathrm{UO}_{2}$ Above $1400^{\circ} \mathrm{C}$

Electrical Conductivity of Single Crystal $\mathrm{UO}_{2}$ Temperature and Frequency Dependence (Specimen EC-S2A)

Electrical Conductivity of Polycrystalline $\mathrm{UO}_{2}$ Temperature and Frequency Dependence (Specimen EC-P1A)

Electrical Conductivity of Polycrystalline $\mathrm{UO}_{2}$ Temperature and Frequency Dependence (Specimen EC-P3A)

Electrical Conductivity of Single Crystal $\mathrm{UO}_{2}$ (B-40-A) Comparing ac and dc Data

Electrical Conductivity of Polycrystalline $\mathrm{UO}_{2}$ (EC-P1A) Comparing ac and dc Data

Electrical Conductivity of Polycrystalline $\mathrm{UO}_{2}$ (EC-P3A) Comparing ac and dc Data

Electrical Conductivity of Polycrystalline U02 (B-38-C) Comparing ac and dc Data

\section{LIST OF TABLES}


ELECTRICAL CONDUCTIVITY OF $\mathrm{UO}_{2}$ :

PART II. FINAL REPORT

\section{INTRODUCTION}

The electrical conductivity of single-crystal $\mathrm{UO}_{2}$ has previously been determined by direct current (dc) measurements from 298 to $3000{ }^{\circ} \mathrm{K} .{ }^{(1)}$ The purpose of this study was to determine the electrical conductivity of singlecrystal $\mathrm{UO}_{2}$ by alternating current (ac) measurements as a function of frequency; and to determine the ac and dc conductivities of polycrystalline, sintered $\mathrm{UO}_{2}$. A statistical analysis of the intrinsic conduction above $1400{ }^{\circ} \mathrm{K}$ was made using a least squares, polynomialfitting, computer program.

Reported effects of grain size and porosity on the extrinsic electrical conductivity of $\mathrm{UO}_{2}$ have been largely incomplete. Wolfe(2) observed a significant difference in extrinsic conductivity as a function of grain size, the larger grain oxide having the higher conductivity. Iida ${ }^{(3)}$ reported that sintered, hypostoichiometric $\mathrm{UO}_{2-\mathrm{x}}$ exhibited a much higher conductivity than the single crystal $\mathrm{UO}_{2-\mathrm{x}}$.

Above temperatures of 1100 to $1300^{\circ} \mathrm{K}$, intrinsic conduction is reported. $(2,4,5)$ In this temperature range $\left(1100\right.$ to $\left.1400^{\circ} \mathrm{K}\right)$ the conduction in nearly stoichiometric $\mathrm{UO}_{2}$ changes from p-type to n-type which is typical of intrinsic semiconductors. The reported activation energies vary from 1.5 to $0.95 \mathrm{eV} .(2,4)$ However, the hightemperature intrinsic data were deter- mined over a relatively small temperature range.

It was thus evident from the available data that electrical conductivity in $\mathrm{UO}_{2}$ at high temperatures was not understood and that there was an important need to determine the electrical conductivity of $\mathrm{UO}_{2}$ by both ac and $\mathrm{dc}$ measurements and to compare the conductivity of single crystal and polycrystalline $\mathrm{UO}_{2}$ over the entire temperature range to $3000^{\circ} \mathrm{K}$.

\section{SUMMARY}

The electrical conductivity of nearly stoichiometric single crystal and polycrystalline $\mathrm{UO}_{2}$ was measured from room temperature to $3000{ }^{\circ} \mathrm{K}$. The electrical conductivity values of polycrystalline $\mathrm{UO}_{2}$ were the same as the values for single crystal $\mathrm{UO}_{2}$. The results show no significant difference between the ac ( 5 to $5000 \mathrm{~Hz}$ ) and dc conductivity values at all temperatures. The electrical conductivity is intrinsic above $1400^{\circ} \mathrm{K}$. The best linear fit of the $1 \mathrm{n} \sigma$ versus $\mathrm{T}^{-1}$ curve above $1400^{\circ} \mathrm{K}$ showed

$$
\sigma=3.57 \times 10^{3} \mathrm{e}^{-1.15 \mathrm{eV} / \mathrm{kt}}
$$

The best fit of the data above $1900{ }^{\circ} \mathrm{K}$ is obtained with the equation

$$
\sigma=2.104 \times 10^{-2} \mathrm{~T}^{1.40} \mathrm{e}^{-0.916 \mathrm{eV} / \mathrm{kT}}
$$




\section{EXPERIMENTAL DETAILS}

\section{URANIUM DIOXIDE SAMPLES}

Electrical conductivity measurements were determined for three single crystal and two polycrystalline specimens. The $\mathrm{UO}_{2}$ single crystal specimens were machined from large crystal boules grown from an arc-fused melt. Crystals were heated for $12 \mathrm{hr}$ in commercial grade hydrogen at $1700{ }^{\circ} \mathrm{C}$ prior to machining. The specimens were of undetermined crystallographic orientation.
The polycrystalline $\mathrm{UO}_{2}$ specimen was machined from a large $\mathrm{UO}_{2}$ cylinder which had been cold pressed and sintered in commercial grade hydrogen at $1700{ }^{\circ} \mathrm{C}$ for $12 \mathrm{hr}$.

Each specimen was heat-treated in the electrical-conductivity apparatus for 8 to $12 \mathrm{hr}$ at $1125^{\circ} \mathrm{K}$ in purified $8 \%$ hydrogen-argon prior to conductivity measurements. (1) The $0: U$ ratio of the crystals after this heat treatment deviated only slightly from stoichiometric $\mathrm{UO}_{2}(0: \mathrm{U}<2.001)$. The $0: \mathrm{U}$ ratio, density, and impurity level of each specimen is given in Table I.

TABLE I. Description of Uranium Dioxide Specimens

A. Single Crystal UO 2

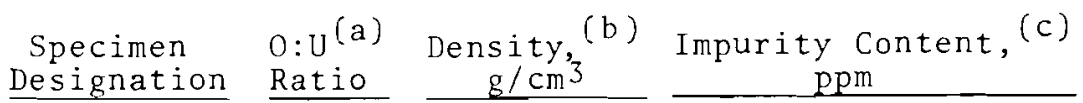

$\begin{array}{lll}\text { MR }-5 & 2.001 & 10.97\end{array}$

A1 2 Cr $<5$ Si 35

As $<2 \quad \mathrm{Fe} 41 \quad \mathrm{Zn}<50$

$\begin{array}{llll}\mathrm{Ca} & 2 & \mathrm{Mg} & 1\end{array}$

$\mathrm{Co}<10 \mathrm{Na}<2$

A11 others total $<1$.

$\begin{array}{lll}\mathrm{B}-40-\mathrm{A} & 2.001 & 10.97\end{array}$

$\begin{array}{llllll}\text { A1 } & 5 & \mathrm{Mg} & 1 & \mathrm{~V} & <50\end{array}$

$\mathrm{Ca} 1 \quad \mathrm{Ni}<5 \quad \mathrm{Zn}<50$

$\mathrm{Cr}<5 \quad \mathrm{~Pb} 3$

Fe 10 Si 21

A1l others total<1.

B. Polycrystalline UO 2

\begin{tabular}{|c|c|c|c|c|c|c|}
\hline$E C-P-3 A$ & 2.001 & 10.39 & $\begin{array}{l}\mathrm{Al} 500 \\
\mathrm{Cr}<5 \\
\mathrm{Cu} 20 \\
\mathrm{Mg} 10 \\
\mathrm{Al1} \text { oth }\end{array}$ & $\begin{array}{l}\mathrm{Mn} 5 \\
\mathrm{Ni}<5 \\
\mathrm{P} 50 \\
\mathrm{~Pb} 5 \\
\text { lers to }\end{array}$ & $\begin{array}{r}\mathrm{Te} \\
\mathrm{V} \\
\mathrm{zn} \\
\mathrm{ta} 1\end{array}$ & $\begin{array}{l}<10 \\
<50 \\
<50 \\
<1 .\end{array}$ \\
\hline$B-38-C$ & 2.001 & 10.19 & $\begin{array}{cc}\mathrm{A} 1 & 1000 \\
\mathrm{Ca} & 2 \\
\mathrm{Cr} & 5 \\
\mathrm{Cu} & 5\end{array}$ & $\begin{array}{ll}\mathrm{Fe} & 66 \\
\mathrm{Mg} & 10 \\
\mathrm{Mo} & 5 \\
\mathrm{Na} & <2\end{array}$ & $\begin{array}{l}\mathrm{Ni} \\
\mathrm{Si} \\
\mathrm{Sn}\end{array}$ & $\begin{array}{l}5 \\
27 \\
<50\end{array}$ \\
\hline$E C-P-1 A$ & 2.001 & 10.29 & $\begin{array}{cl}\mathrm{A} 1 & 1000 \\
\mathrm{Bi} & 1 \\
\mathrm{Ca} & 5 \\
\mathrm{Cr} & <5\end{array}$ & $\begin{array}{l}\mathrm{Cu} 0.5 \\
\mathrm{Fe} 43 \\
\mathrm{Ge}<0.5 \\
\mathrm{Mg} 5\end{array}$ & $\begin{array}{l}\mathrm{Mo} \\
\mathrm{Na} \\
\mathrm{Ni} \\
\mathrm{Si} \\
\mathrm{Sn} \\
\mathrm{V}\end{array}$ & $\begin{array}{l}<5 \\
<2 \\
5 \\
27 \\
<5 \\
<50\end{array}$ \\
\hline
\end{tabular}

A11 others $<1$.

(a) 0:U were determined by coulometry after electrical conductivity measurements.

(b) Determined by mercury dispzacement.

(c) Determined by emission spectroscopy. 


\section{ELECTRICAL-CONDUCTIVITY APPARATUS}

Electrical conductivity was measured using a four-contact method (Figure 1). A tungsten mesh element with a hot zone, $3.5 \mathrm{~cm}$ diam and $9 \mathrm{~cm}$ long, was heated by direct current from motor-driven generators. The oxide specimens $(0.63$ $\mathrm{cm}$ diam and $1.9 \mathrm{~cm}$ long) were held in the furnace between two tungsten holders. These holders were also used as current leads during conductivity measurements. Two sharp-pointed, tungsten rods were set into very shallow holes $0.63 \mathrm{~cm}$ apart on the specimen surface to measure the voltage drop across the specimen. Good contacts were main-

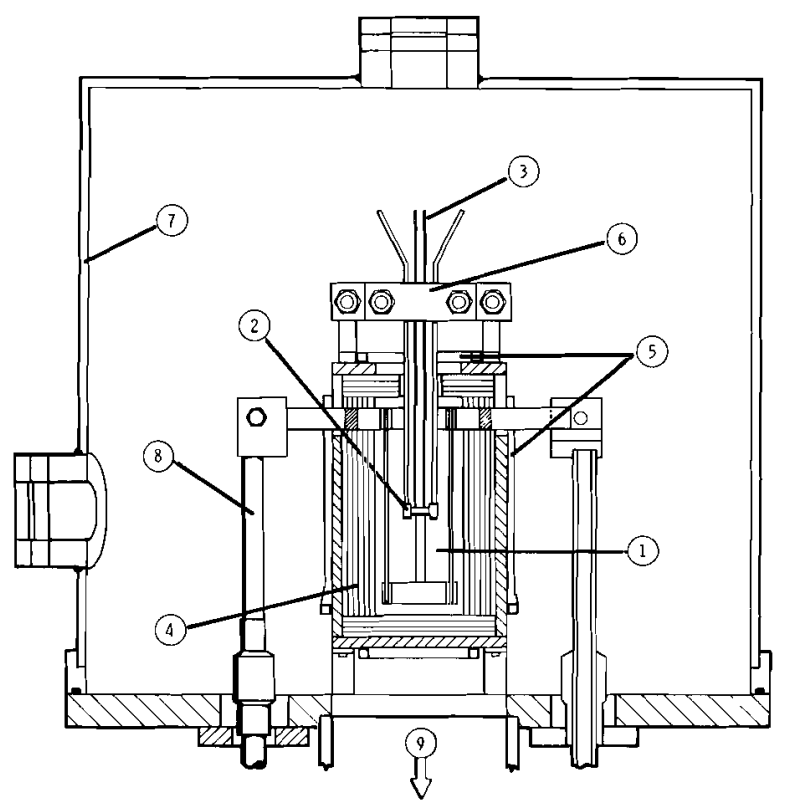

\footnotetext{
TUNGS TEN MESH HEATING ELEMENT TUNGS TEN SPECIMEN HOLDERS TUNGS TEN VOLTAGE PROBES HEAT SHIELDS
}

5 WATER COOLED - COPPER SHIELD 6 CERAMIC INSULATOR WATER - COOLED ALUMINUM BELL JAR WATER - COOLED ELECTRIC TERMINALS to VACUUM SYSTEM tained by applying a small pressure to these probes. Since no current was permitted to flow through these probes, relatively high contact resistances could be tolerated.

The electrical measurement consisted of passing a constant alternating or direct current through the specimen and measuring the resulting potential difference between the two probes, (Figure 2). Direct current was provided from a solid-state power supply. The direction of the current was reversed as rapidly as possible and the current-voltage relationship was measured with current flow in both directions. An average of the two values was used to calculate the resistance. The alternating current was provided from a wide-range oscillator $(5 \mathrm{~Hz}$ to $600 \mathrm{kHz}$ ). Most measurements were made

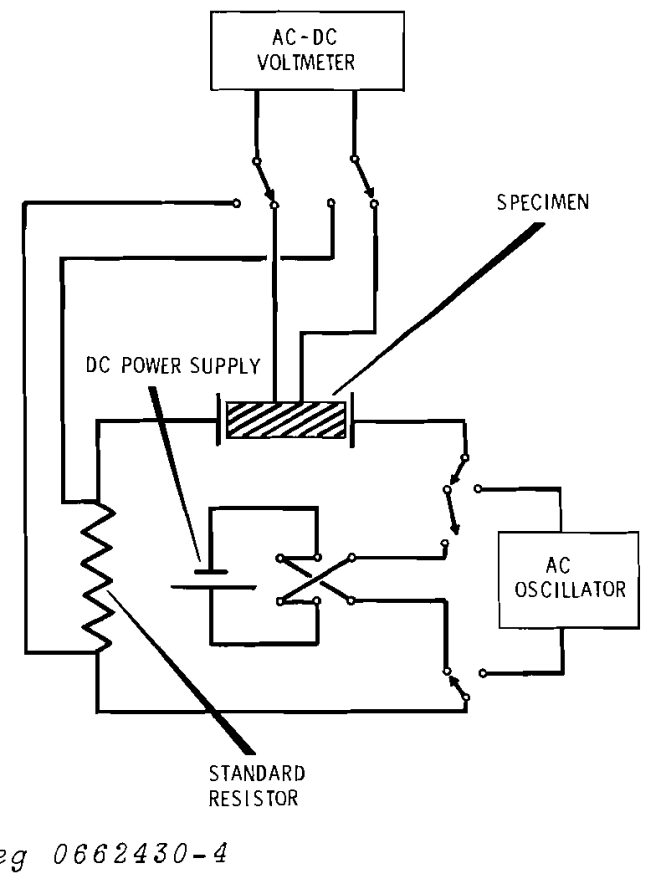

EIGURE 2. Schematic Representation of the Electrical Circuit for the Four Probe, Electrical Conductivity Apparatus
FIGURE 1. Schematic Representation of Four Probe, Electric Conductivity Apparatus 
at frequencies less than $5000 \mathrm{~Hz}$ since measurements were complicated by a frequency dependence of the measuring circuit not associated with the oxide specimens. No frequency dependence of the conductivity was observed between 5 to $5000 \mathrm{~Hz}$. Voltages were measured with a high resistance voltmeter. The current through the specimen was determined by measuring the voltage difference across a standard resistor in series with the specimen. The size of the resistor varied from 2.5 to 1000 ohms to provide the best currentvoltage combination.

The measuring potential was varied between 0.01 and $10 \mathrm{~V}$ with most measurements between 0.01 to $1.0 \mathrm{~V}$. The current through the specimen varied between 1 and $100 \mathrm{~mA}$.

A switching device was used to conveniently change from the ac to dc measuring circuit. Approximately 10 to $30 \mathrm{sec}$ were required for both ac and dc measurements at any one temperature.

\section{ATMOSPHERE}

Measurements were made in purified $8 \%$ hydrogen-92: argon at atmospheric pressure. The oxygen and water content of the gas introduced into the furnace was $<1 \mathrm{ppm}$ and $<5 \mathrm{ppm}$, respectively. The partial pressure of oxygen during measurements at high temperatures was calculated using thermodynamic data for the decomposition of water in hydrogen. The calculated partial pressures of oxygen at 1125, 2025, and $2675^{\circ} \mathrm{K}$ were $2.5 \times 10^{-26}, 6.3 \mathrm{x}$ $10^{-14}$, and $8 \times 10^{-13}$ atmospheres, respectively.
Measurements were initially made in purified dry argon and $8 \%$ hydrogenargon with a relatively high water content. However, the measurements in the low-temperature range in these atmospheres were not reproducible during thermal cycles, apparently because of 0 :U changes in the relatively nonreducing atmosphere.

\section{TEMPERATURE MEASUREMENTS}

Temperatures were measured from 298 to $1850^{\circ} \mathrm{K}$ using a Pt-Pt $13 \%$ Rh thermocouple positioned adjacent to the sample. At the higher temperatures the thermocouples were removed and temperatures were measured above $1050{ }^{\circ} \mathrm{K}$ with an optical brightness pyrometer. The system was calibrated using a $\mathrm{UO}_{2}$ sample with a $0.040 \mathrm{~cm}$ diam, $0.32 \mathrm{~cm}$ deep hole drilled into the center of the rod. Corrections were made for the absorption of the pyrex window. Both thermocouple and pyrometer temperatures agreed to within $\pm 5^{\circ} \mathrm{K}$ in the temperature range from 1100 to $1850^{\circ} \mathrm{K}$ where both measurements could be made simultaneously. No temperature gradient across the sample was observed.

Measurements were made during both increases and decreases in temperature during a thermal cycle. The rate of temperature change (stepwise) was varied from approximately $2{ }^{\circ} \mathrm{K} / \mathrm{min}$ to approximately $25^{\circ} \mathrm{K} / \mathrm{min}$.

\section{RESULTS AND DISCUSSION}

The electrical conductivity below $125^{\circ} \mathrm{K}$ was not reproducible during 
the initial measurements of a nonheat-treated specimen or when measurements were conducted in purified argon (1ppm $\mathrm{O}_{2}$ and $<10$ ppm $\mathrm{H}_{2} \mathrm{O}$ ) or in $8 \%$ hydrogen-argon with a relatively high water content (approximately $100 \mathrm{ppm}$ ). (1) A hysteresis in the electrical conductivity occurred below $1250^{\circ} \mathrm{K}$ during thermal cycling. The conductivity was higher on heating than during cooling. Above approximately $1250^{\circ} \mathrm{K}$, the conductivity values were the same in all atmospheres.

To eliminate the effects of the residual oxygen, measurements were made in a reducing atmosphere of $8 \%$ hydrogen-92\% argon. Data which are reported represent reproducible conductivity values from as many as five thermal cycles from room temperature to $3000^{\circ} \mathrm{K}$.

Similar changes in $\mathrm{UO}_{2}$ electrica] conductivity in this temperature range ( 300 to $1150{ }^{\circ} \mathrm{K}$ ) have been observed by other investigators. $(2,6-13)$ This nonreproducibility has been attributed to stoichiometric changes during heating resulting from the high oxygen content of the inert gases. Wolfe $(2)$ suggested that the variations were probably due to the oxidation of the specimen surface and not a homogeneous change in specimen stoichiometry.

Initial ac measurements indicated that the electrical conductivity of both polycrystalline and single crystal $\mathrm{UO}_{2}$ increased with increasing frequency above $5 \mathrm{kHz}$ at low temperatures and decreased with increasing frequency above $5 \mathrm{kHz}$ at temperatures above $1250^{\circ} \mathrm{K}$ (See Appendix A). Because of the unusual nature of these results, further ac measurements were performed using other materials (such as graphite) to determine if these results were characteristic of the $\mathrm{UO}_{2}$ or of the measuring system. The results indicated that high-frequency resistancc effects in the measuring system could have caused these changes in conductivity. For this reason, all ac conductivity data above $5 \mathrm{kHz}$ are questionable. Further tests will be required to determine if a frequency dependence of conductivity exists for $\mathrm{UO}_{2}$. The low-frequency data $(<5 \mathrm{kHz})$ where conductivity is independent of frequency are accurate and are reported in this study.

The ac $(<5 \mathrm{kHz})$ electrical conductivity of $\mathrm{UO}_{2}$ is identical within experimental error to the dc electrical conductivity at all temperatures (Figure 3).* No time dependence of the conductivity was observed between 1 and $60 \mathrm{sec}$. The similarity of the ac and dc conductivity suggests that the conduction in nearly stoichiometric $\mathrm{UO}_{2}$ is primarily electronic.

The electrical conductivity values for polycrystalline $\mathrm{UO}_{2}$ were the same at a11 temperatures as the conductivity values for single crystal $\mathrm{UO}_{2}$ (Figure 4). It can be concluded that for near1y stoichiometric $\mathrm{UO}_{2}$, there is no significant attenuation of the electronic carriers due to grain boundaries or pores. In light of these results, it is difficult to understand the data reported by Wolfe (2) which showed an increase in conductivity with grain

\footnotetext{
* The electrical conductivity data for all Uo, specimens are given in Appendix $B$.
} 
size for nearly stoiochiometric $\mathrm{UO}_{2}$, and the very large increase in conductivity of polycrystalline, hypostoichiometric $\mathrm{UO}_{2}$ observed by Iida over single crystal $\mathrm{UO}_{2}$ of the same stoichiometry.

The electrical conductivity of polycrystalline $\mathrm{UO}_{2}$ for both $\mathrm{ac}$ and $\mathrm{dc}$ measurements shows the same variations in $\log$ o versus $\mathrm{T}^{-1}$ curve below $1250^{\circ} \mathrm{K}$ that was observed for single crystal

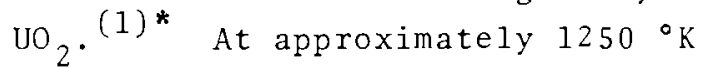
there is a sharp break in the $\log \sigma$ versus $\mathrm{T}^{-1}$ curve where the conduction

* The electrical conductivity data for al2 $\mathrm{UO}_{2}$ specimens are given in Appendix $B$.

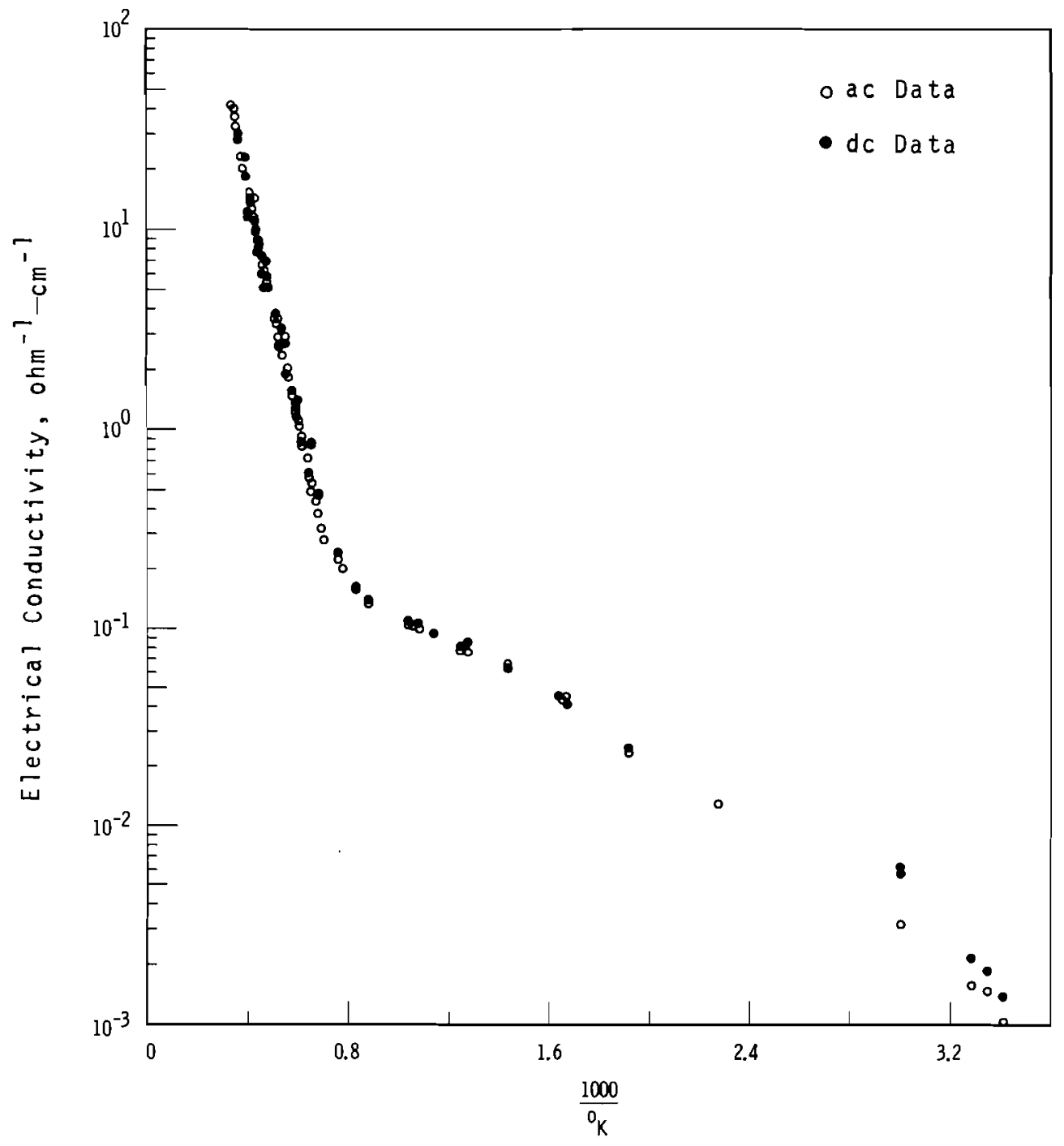

Neg 0671421-3

FIGURE 3. The Electrical Conductivity of Polyorystalline UO $2(B-38-C)$ Comparing the ac and de Electrical Conductivity Data 


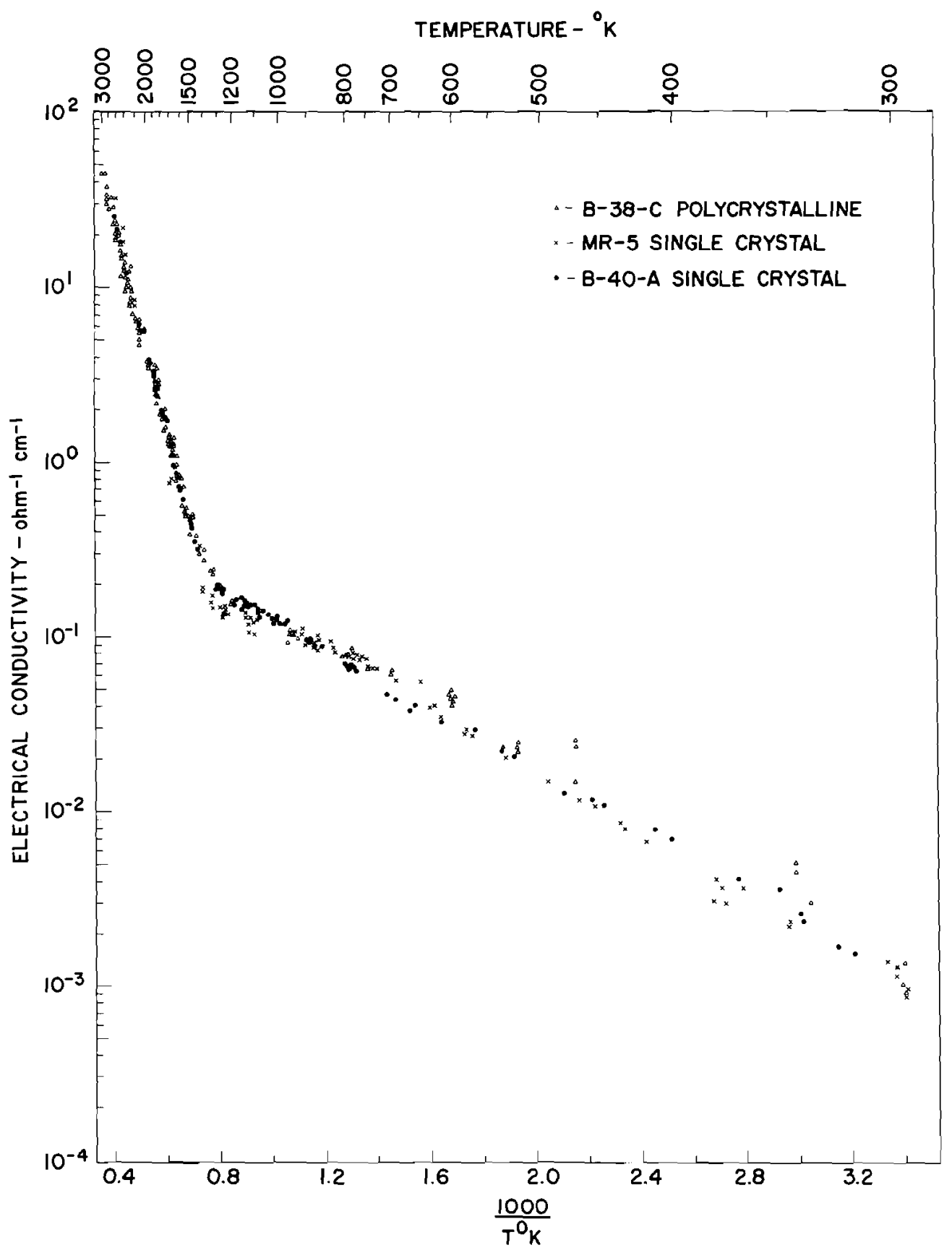

$\operatorname{Neg} 0670767-1$

FIGURE 4. The Electrical Conductivity of Polycrystalizine and Single Crystal Uranium Dioxide Including Both ac and dc Measurements 
is intrinsic n-type with an activation energy above $1.0 \mathrm{eV}$.

Below $575^{\circ} \mathrm{K}$ the $\log \sigma$ versus $\mathrm{T}^{-1}$ curve for all the specimens appears to be 1 inear with an activation energy of approximately $0.17 \mathrm{eV}$ (Figure 4). The conductivity values at any single temperature varies between samples; however, the slope is approximately the same.

Above $575^{\circ} \mathrm{K}$, however, an effect occurs that causes a change in slope. Single crystal B-40-A exhibits an "S" shape between 575 and $1250^{\circ} \mathrm{K}$. The curves for single crystal MR-5 and polycrystalline B-38-C appear as humps. However, the change in slope for B-38-C occurs at a higher temperature, approximately $675^{\circ} \mathrm{K}$. These changes are reproducible and occur both on heating and cooling.

Such differences between specimens can result from differences in impurity content or in stoichiometry. However, the differences in conductivity are small compared to the differences in impurity content between samples (See Table I). The stoichiometry of the samples is the same to within the accuracy of the analytical measurements.

Similar changes in slope of the log 0 versus $\mathrm{T}^{-1}$ curve have been observed by other investigators. Wolf $\mathrm{e}^{(2)} \mathrm{ob}$ served a break in the curve at $675^{\circ} \mathrm{K}$ for polycrystalline $\mathrm{UO}_{2}$ similar to that observed in polycrystal1ine sample $B-38-C$. He reported on activation energy of $0.13 \mathrm{eV}$ between 675 and $1250^{\circ} \mathrm{K}$. The slope for $\mathrm{B}-38-\mathrm{A}$ is approximately the same. However, the activation energy for data of Wolfe below $675^{\circ} \mathrm{K}$ was $0.20 \mathrm{eV}$, slightly higher than the $0.17 \mathrm{eV}$ observed in these data. Wolfe (2) suggests that above $675^{\circ} \mathrm{K}$, the activation energy $(0.13 \mathrm{eV})$ represents that of the trans fer of a positive hole from $\mathrm{U}^{5+}$ cation to an adjacent $\mathrm{U}^{4+}$ cation. The activation energy $(0.20 \mathrm{eV})$ below $675^{\circ} \mathrm{K}$, in addition to the energy of the jump process, includes the energy for freeing holes that are bound to defect centers. Amelinckx, et al. (11) observed a similar change in slope at approximately $475^{\circ} \mathrm{K}$; this change was most pronounced in specimens that had been quenched. He attributed this change to the phase transition in the specimen from $\mathrm{UO}_{2+x}$ to $\mathrm{UO}_{2}$ plus $\mathrm{U}_{4} \mathrm{O}_{9}$.

Iida (3) detected a rapid change in conductivity near $175^{\circ} \mathrm{K}$ which he attributed to a high impurity concentration.

Other possible causes could involve changes in the thermally activated process (e.g., in addition to the mobility, the carrier density might also be changing). The effect would also be even more complex, if the difference in charge between the polarized ion and lattice ion was greater than unity. Further measurements to lower temperatures and measurements as a function of oxygen pressure may be required to clarify the exact cause of this change.

The electrical-conductivity data has been plotted in the form $\log \sigma$ versus $\mathrm{T}^{-1}$ and the activation energy reported here is obtained from the relation

$$
\sigma=\sigma_{0} e^{-E / k T}
$$

Although the correct temperature relationship for the hopping mechanism has not been clearly determined, other 
investigators have used a plot of $10 \mathrm{~g}$ $\sigma \mathrm{T}$ versus $\mathrm{T}^{-1}$, calculating their activation energy from the expression

$$
\sigma=\sigma_{0} \frac{1}{T} e^{-E / k T}
$$

The activation energy using the 1 atter method is approximately $20 \%$ higher than the value obtained from a $\log \sigma$ versus $\mathrm{T}^{-1}$ curve. The $\log \sigma \mathrm{T}$ versus $T^{-1}$ curve did not improve the Iinearity of the data in this temperature range.

Above $1250^{\circ} \mathrm{K}$, there is a sharp rise in the electrical conductivity. The data for all of the specimens show a similar reciprocal temperature relationship indicating intrinsic conduction. This large change in activation energy at $1250^{\circ} \mathrm{K}$ corresponds to the p-to-n transition observed in the rmoelectric property measurement. (9) Evidence for the existence of intrinsic conduction has also been reported by willardson, et a1. (6) and by Wolfe. (2)

The intrinsic electrical conductivity of solids can be given by

$$
\sigma=n \varepsilon \mu \text {. }
$$

where $n$ is the intrinsic carrier concentration, $\varepsilon$ is the electronic charge, and $\mu$ is the carrier mobility. The electronic charge is constant. The mobility of an electron or hole does not change significantly above the characteristic temperature. (For $\mathrm{UO}_{2}$ the characteristic temperature is $\left.<300{ }^{\circ} \mathrm{K}\right)$. (5) The carrier concentration based upon the quantum mechanical treatment of free electron carriers in a nondegenerate state can be expressed as

$$
n=\frac{2\left(2 \pi m^{*}\right.}{h^{3}} \frac{k T)^{3 / 2}}{-E g^{/ 2} k T}
$$

where $m^{*}$ is the effective mass and $E_{g}$ is the energy difference between the valence and conduction bands. This equation also assumes that $m^{*}=m_{+}^{*}=$ $m_{-}^{*}$ and $n=\left(n_{-} n_{+}\right)^{1 / 2}$, i.e., the Fermi level lies exactly between the valence and conduction bands. Thus, the equation for conductivity is given as

$\sigma=\varepsilon \mu \frac{2\left(2 \pi m^{*} k T\right)^{3 / 2}}{h^{3}} e^{-E_{g} / 2 k T}$.

For temperatures where $2 \mathrm{kT} \ll \mathrm{E}_{\mathrm{g}}$, the exponential term is very much more important than $\mathrm{T}^{3 / 2}$. The equation is then approximated to the familiar form

$$
\sigma=\sigma_{0} e^{-E_{g} / 2 k T}
$$

where $\sigma_{0}$ is a constant and $E_{g}$ is twice the activation energy, E. By plotting $\log \sigma$ as a function of $\mathrm{T}^{-1}$, the activation energy may be obtained from the slope of the straight 1 ine.

The least square curve of $\log \sigma$ versus $\mathrm{T}^{-1}$ above $1400^{\circ} \mathrm{K}$ was determined for each specimen and for the combined data from the three specimens (Table II). The results show no significant differences in the conductivities of single crystal and polycrystalline $\mathrm{UO}_{2}$, nor between the ac and dc data. A reasonable linear fit of the data is obtained with the activation energies varying from 1.14 to $1.21 \mathrm{eV}$. For all data, the electrical conductivity above $1400^{\circ} \mathrm{K}$ can be expressed as

$$
\sigma=3.569 \times 10^{3} \mathrm{e}^{-1.15 / \mathrm{kT}} .
$$


TABLE II. Linear Fit of Electrical Conductivity of UO ${ }_{2}$ Above $1400^{\circ} \mathrm{K} \sigma=\sigma_{0} e^{-E / K T}$

\begin{tabular}{|c|c|c|c|c|}
\hline Specimen & Data Points & $\begin{array}{r}\sigma o \\
\mathrm{mho} / \mathrm{cm} \\
\end{array}$ & $\begin{array}{r}\text { Activation Energy, } \\
\mathrm{eV}\end{array}$ & $\begin{array}{l}\text { Standard (a) } \\
\text { Deviation }\end{array}$ \\
\hline MR - 5 & 24 & $5.240 \times 10^{3}$ & 1.212 & 0.0068 \\
\hline$B-40-A$ & 36 & $4.141 \times 10^{3}$ & 1.168 & 0.0015 \\
\hline$B-38-C$ & 133 & $3.370 \times 10^{3}$ & 1.144 & 0.00098 \\
\hline ECP $3 A$ & 21 & $3.255 \times 10^{3}$ & 1.058 & 0.0113 \\
\hline A11 Data & 193 & $3.569 \times 10^{3}$ & 1.151 & 0.00056 \\
\hline
\end{tabular}

(a) $95 \%$ Confidence Level

Although a reasonable fit of the data is obtained from a linear equation, a better fit of the data is obtained statistically with a third order polynomial. For all data

$\ln \sigma=9.046-2.087 \times 10^{4} \mathrm{~T}^{-1}+1.231$

$$
\times 10^{7} \mathrm{~T}^{-2}-6.484 \times 10^{9} \mathrm{~T}^{-3} \cdot(6)
$$

These results show that the slope of the en $\sigma$ versus $\mathrm{T}^{-1}$ curve above $1900{ }^{\circ} \mathrm{K}$ increases slightly with increasing temperature. A plot of $\frac{\Delta(\ell n \sigma)}{\Delta\left(T^{-1}\right)}$ versus temperature is shown in Figure 5. Above $1900^{\circ} \mathrm{K}$, the incrementally determined slope varies linearly with temperature as

$\frac{\Delta(\ell \mathrm{n} \sigma)}{\Delta\left(\mathrm{T}^{-1}\right)}=-10.627 \times 10^{3}-1.4013 \mathrm{~T} .(7)$ Between 1400 and $1900^{\circ} \mathrm{K}, \frac{\Delta(\ell \mathrm{n} \sigma)}{\Delta\left(\mathrm{T}^{-1}\right)}$ varies only slightly with temperature. From Equation 3, the temperature dependence of $\sigma$ above $1900^{\circ} \mathrm{K}$ can be expressed as

$$
\sigma=\sigma_{0}^{1} T^{3 / 2} e^{-E^{\prime} / 2 k T}
$$

or

$\ln \sigma=\ln \sigma_{0}^{1}+3 / 2 \ln \mathrm{T}-\frac{E^{\prime}}{2 k T}$.

It can be easily shown by differentiation that

$$
\frac{\Delta(\ln \sigma)}{\Delta\left(\mathrm{T}^{-1}\right)}=-\frac{E^{\prime}}{2 \mathrm{k}}-\frac{3}{2} \mathrm{~T} \text {. }
$$

This is the same form as Equation (7) obtained from a plot of the data above $1900^{\circ} \mathrm{K}$ (Equation 7) where

$$
\begin{gathered}
\sigma=2.104 \times 10^{-2} \mathrm{~T}^{1.401} \\
\mathrm{e}^{\frac{-0.9157 \mathrm{eV}}{\mathrm{kT}}} .
\end{gathered}
$$

This would suggest that above 1900 ${ }^{\circ} \mathrm{K}$, the $\mathrm{T}^{3 / 2}$ cannot be neglected. $\Lambda t$ $2000^{\circ} \mathrm{K}, 2 \mathrm{kT}$ is approximately 0.1 the activation energy and $2 \mathrm{kT}$ is not $<<\mathrm{E}_{\mathrm{g}}$. It is interesting to note that the power of $\mathrm{T}$ from the data $(1.401)$ is close to the theoretical value of 1.5 .

The exact meaning of the $0.916 \mathrm{eV}$ for $E^{\prime}$ is somewhat obscure since it applies only to the data above $1900^{\circ} \mathrm{K}$. 
It need not agree with the activation energy obtained from the linear curve ( $1.15 \mathrm{eV}$ ) since the activation energy could be a func ion of temperature without altering the slope of the en o versus $T^{-1}$ curve, $\left(E_{g}=E_{0}+\alpha T\right)$. It can be shown that the $a / k$ term would become a part of the $\sigma_{0}$ term during differentiation.

Although there is a significant statistical difference between the first and third order relationships for the conductivity, the linear equation is representative of the data within experimental error. It can be concluded that until more data are available for many $\mathrm{UO}_{2}$ specimens, the best expression of conductivity above $1400^{\circ} \mathrm{K}$ is linear Equation (5).

A significant difference exists between the energy gap derived from con- ductivity data $(2.3 \mathrm{eV})$ and that derived from optical absorption data. (5) of the reported values for the optical energy gap (2.0 to $5.25 \mathrm{eV})$, the highest is probably the most valid. The lower energy values were determined by using thin sections where absorption densities are very large and a measurement of the absorption edge is very difficult. (12) In addition, in very thin sections, single crystals appear yellow in transmitted light, (5) suggesting an optical energy gap greater than $2.0 \mathrm{eV}$. As suggested by Wolfe, (2) the absorption spectrum for $\mathrm{UO}_{2}$ between 2000 and 7000 A probably consists of a strong absorption edge at $2400 \AA(5.25 \mathrm{eV})$, two intense bands between $2500 \mathrm{~A}(5.0 \mathrm{eV})$ and $5000 \AA(2.5 \mathrm{eV})$ with an absorption edge near $6600 \AA(2.00 \mathrm{eV})$.

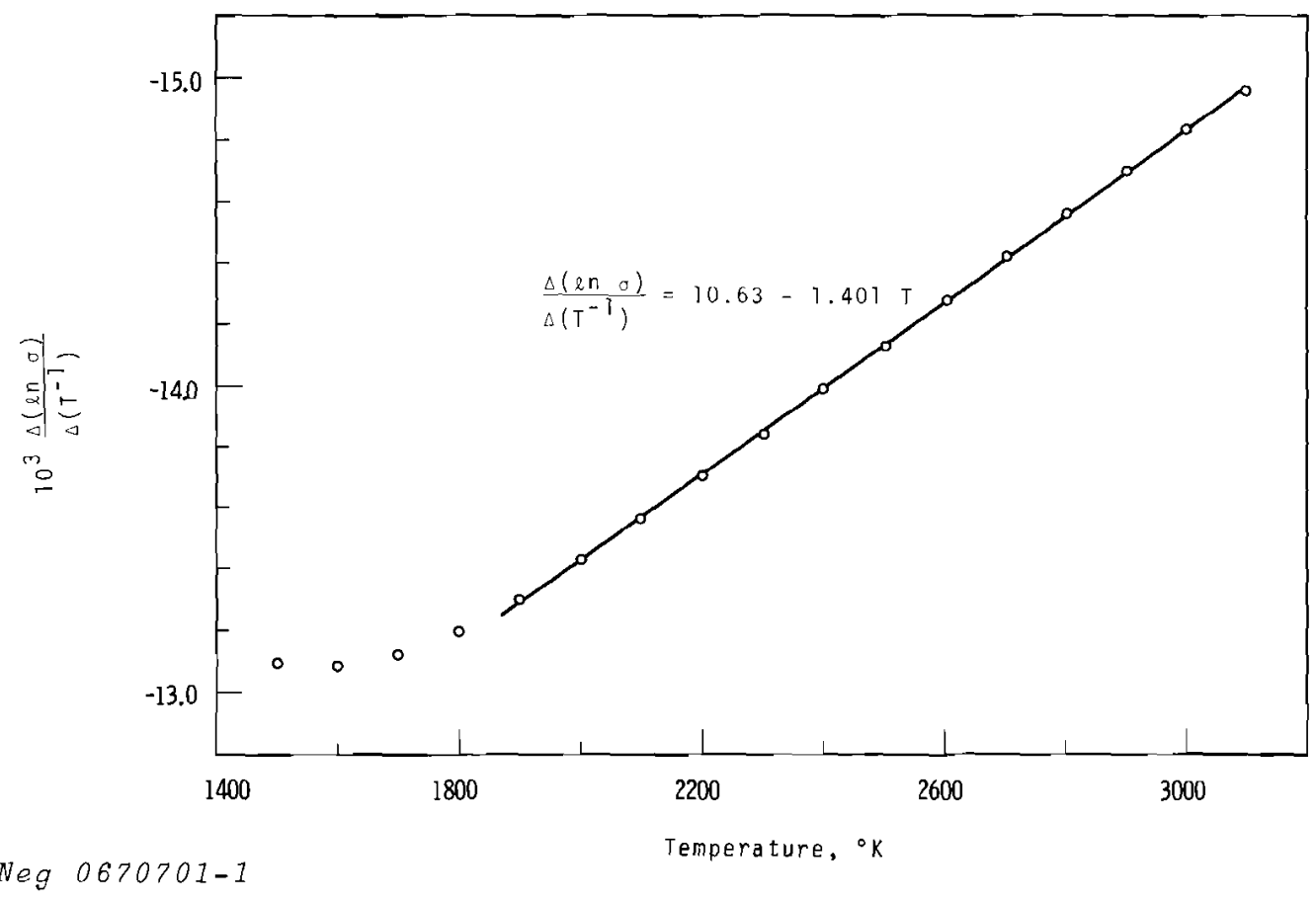

FIGURE 5. The Temperature Dependence of $\frac{\Delta(\ln \sigma)}{\Delta\left(T^{-1}\right)}$ for the Intrinsic Electrical 
A direct numerical agreement between the thermal energy gap and the optical energy gap should not be expected in polar solids. $(12-15)$ The optical energy transition occurs without relaxation obeying selection rules which require no change of momentum. The thermal energy transition occurs with an energy change in equilibrium configuration. The selection rules may be relaxed, if the electron (or hole) interacts with the lattice and the transition is accompanied by the emission or absorption of a phonon. This latter energy is measured from electrical conductivity data. Thus, the optical energy gap should always be larger than the thermal energy gap, making it difficult to compare directly the absorption energy spectra and electrical conductivity data.

An additional distinction exists between the thermal and optical energy gap in polar crystals. The redistribution of ionic charge can change the relative configuration of the bands. This change is a relatively slow, thermally-activated process. During the faster, optical excitation process, this charge redistribution does not occur. The differences in the thermal and optical excitation processes can be described in terms of the low frequency $\left(\varepsilon_{s}\right)$ and high frequency $\left(\varepsilon_{0}\right)$ dielectric constants. This difference is proportional to $\left(\varepsilon_{S}-\varepsilon_{0}\right) / \varepsilon_{S} \varepsilon_{0}$. (14)

If $\varepsilon_{S}$ is larger than $\varepsilon_{0}$ as is probable in ionic crystals, the optical energy gap would be larger than the thermal energy gap.

The ratio of the optical to thermal energy transitions is approximately equal to $\varepsilon_{s} / \varepsilon_{0} \cdot{ }^{(5)}$ This value for $\mathrm{UO}_{2}$ has been reported as 24/5.8. (5) Assuming the optical energy gap is $5.25 \mathrm{eV}$, the corresponding thermal energy gap would be $1.27 \mathrm{eV}$, substantially less than half the measured value.

However, a simple band model is as sumed in this analysis, and it has been pointed out previously that simple band theory may not be valid for $\mathrm{UO}_{2}$. Thus, a correlation of electrical and optical properties is complicated and does not appear feasible using present theory.

The difference between the optical and thermal energy gaps could also indicate the presence of an intense extrinsic band in $\mathrm{UO}_{2}$ near $2.3 \mathrm{eV}$. This band would be independent of $0: U$ ratio of the $\mathrm{UO}_{2}$ and the conductivity associated with this band would mask the true intrinsic conductivity representative of the higher $(\sim 5.0 \mathrm{eV})$ energy gap. 


\section{REFERENCES}

1. J. L. Bates, C. A. Hinman and T. Kawada. Electrical Conductivity of U0 : Part I, Single Crystals, BNWL-296 PT 1, Pacific Northwest Laboratory, Richland, washington, August, 1966 .

2. R. A. Wolfe. The Electrical Conductivity and Thermoelectric Power of Uranium Dioxide, WAPD270, Westinghouse Atomic Power Department, Pittsburgh, Pennsyzvania, 1963.

3. Shoji Iida. "EZectrical Properties of Nonstoichiometric Uranium Dioxide," Jap. J. Appl. Phys. vol. 4, no. 11, pp. 833-838. 1965.

4. R. K. Wilzardson and J. M. Moody. "Electrical, Magnetic, and optical Properties," Uranium Dioxide: Properties and Nuclear Applications, $J$. Belze, edited by U. S. Government Printing office, Washington, D. C., pp. 211-219. 1961 .

5. Thermodynamic and Transport Properties of Uranium Dioxide and Related Phases, Technical Report Series No. 39, International Atomic Energy Agency, Vienna, Austria, pp. 6072. 1965 .

6. R. K. Wilzardson, J. W. Moody and H. L. Goering. "The Electrical Properties of Uranium Dioxide," J. Inorg. Nucl. Chem. vol. $6, p p$. $19-33.1958$.

7. P. Chiotti. "II. Crucibles of Mixtures of Tuballoy Dioxide with Other Materials," in Technological Research--Metalzuray for Period Oetober 10 to November 10, 1944, $p p \cdot 7-8 \cdot 1945$.
8. S. Aronson, J. E. RulZi and Be. E. Schaner. "Electrical Properties of Nonstoichiometric Uranium Dioxide," J. Chem. Phys., vol. 35, pp. $1382-\overline{1388.1961 .}$

9. J. L. Bates. "Ionic Diffusion in High Temperature Uranium Dioxide," Symposium on Thermodynamics with Emphasis on Nuclear Materials and Atomic Transport in Solids, paper no. Sm-66/67, IAEA Vienna, Austria, euzy $22-27$.

10. R. J. Ackerman, R. J. Thom and G. H. Winslow. "Visibie and Ultraviolet Absorption Properties of Uranium Dioxide Tilms," J. Opt. Soc. Am., vol. 49, no. 11, $\overline{p p \cdot 1107-}$ $111 \overline{2} .1959$.

11. S. Amelinckx. Physical Properties of Uor single crustals, EUR 1414.e, Centre d'Etude de l'Energie Nucleaire, MOL, Belgium. 1965.

12. J. I. Bates. "Visible and Infrared Absorption Spectra of Uranium Dioxide," Nucl. Sei. and Eng., vol. 21, pp. 26-29. 1965 .

13. N. F. Mott and R, W. Gurnery. EZectronic Processes in Ionic Crystals. Oxford University Press, London, 1953. 2nd ed., pp. 160-162.

14. W. W. Scanzon. "Polar Semiconductors," Solid state Phisies, Academic Press, New York, 1959, vol. 9, pp. $109-118$.

15. E. J.W. Verwey. "Oxidic SemiConductors," Semi-Conducting Materials, edited by $\bar{R}$. W. Ditchburn and N. F. Mott. Butterworths Scientific Publication, Lta., London, 1951.p.151-161. 


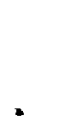

. 


\section{APPENDIX A \\ FREQUENCY DEPENDENCE OF ELECTRICAL CONDUCTIVITY OF UO 2}

Initial measurements of the ac electrical conductivity of both polycrystalline and single crystal $\mathrm{UO}_{2}$ exhibited unusual frequency dependencc above $50 \mathrm{kHz}$. However, further measurements above $50 \mathrm{kHz}$ were performed on other materials (such as graphite). The results suggested that the high frequency changes in conductivity were probably due to resistance effects in the measuring system. For this reason all ac data above $10 \mathrm{kHz}$ can be questioned. Further study and refinement of the equipment will be required to determine if a frequency dependence of conductivity exists for $\mathrm{UO}_{2}$. Two examples of the frequency dependence are illustrated in Figures A-1 through A- 3 .

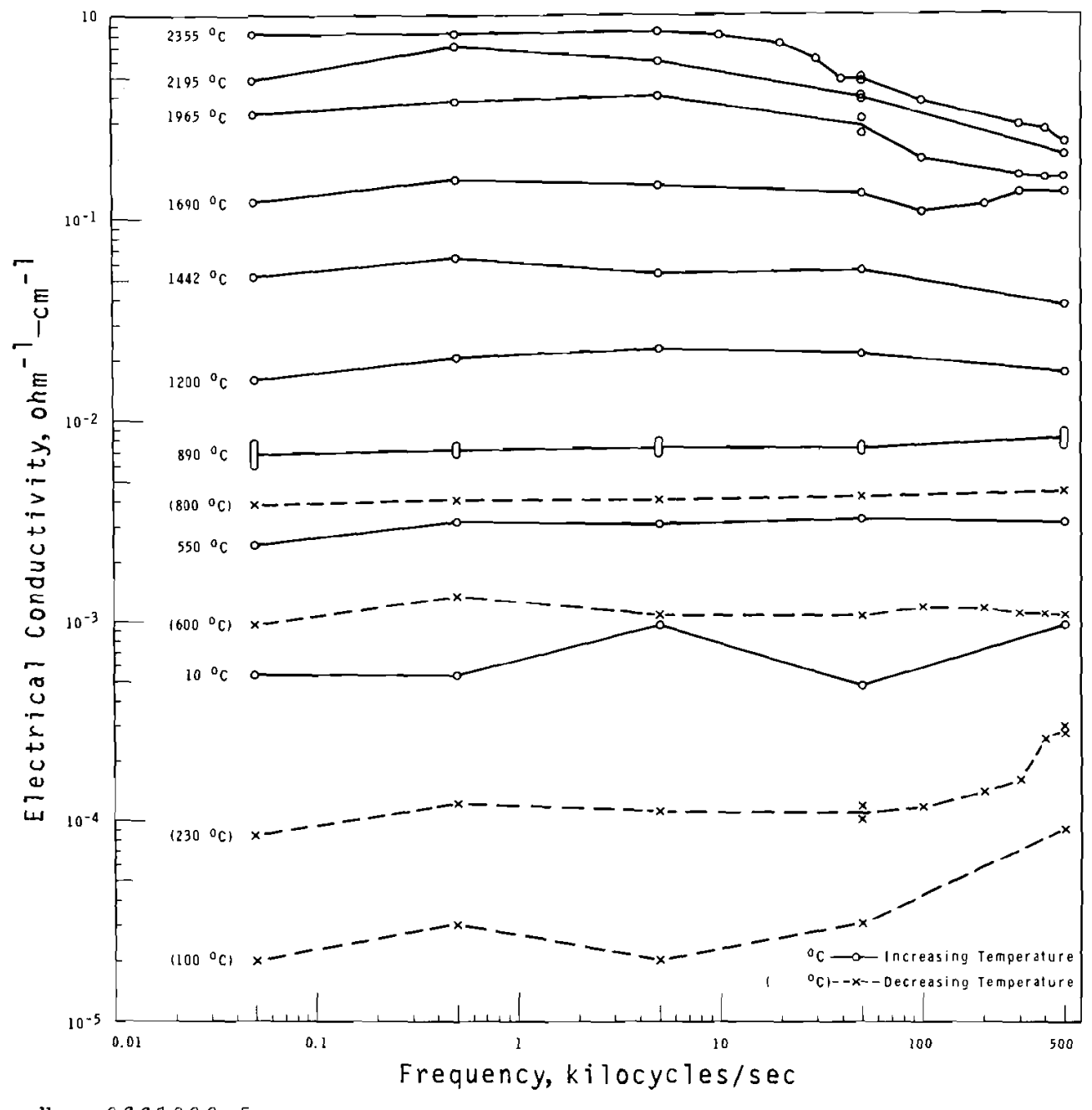

Neg 0661000-5

FIGURE $A-1$. Electrical Conduetivity

of Single Crystal UO Temperature and

Frequency Dependence (Specimen EC-S2A) 
The polycrystalline $\mathrm{UO}_{2}$ appeared to exhibit more pronounced changes than the single crystal oxide. In addition, the values of the conductivity were different during increasing or decreasing temperature changes during a the rmal cycle.
The exact cause of these variations is not known. It has been suggested that the frequency variations are due to the resistance of the voltage probes or current leads, or to surface conduction effects which are strongly frequency dependent.

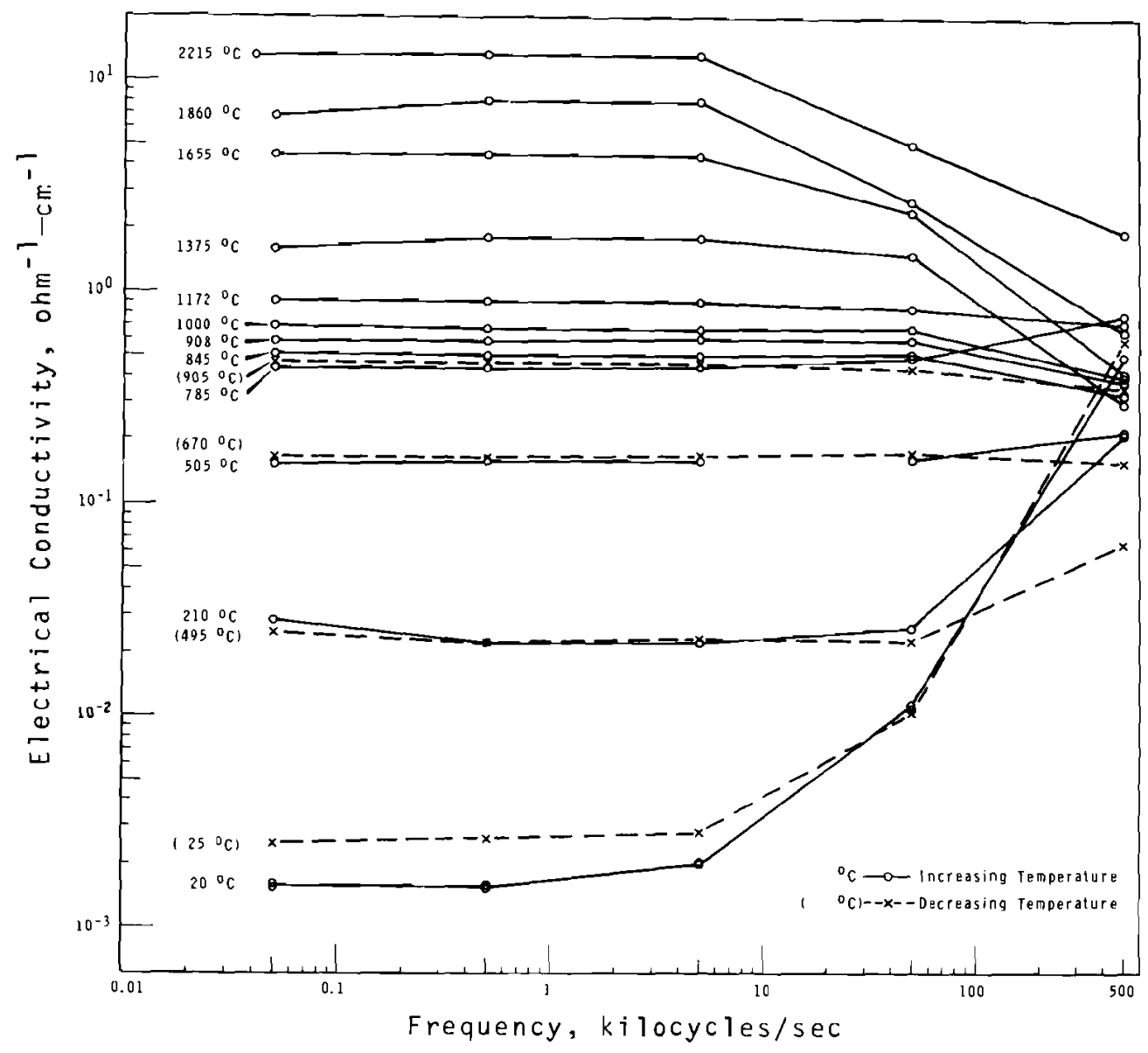

Neg $0661000-6$

FIGURE A-2. Electrical Conductivity of Polycrystali ine UO ${ }_{2}$ Temperature and Erequency Dependence (Specimen EC-PIA) 


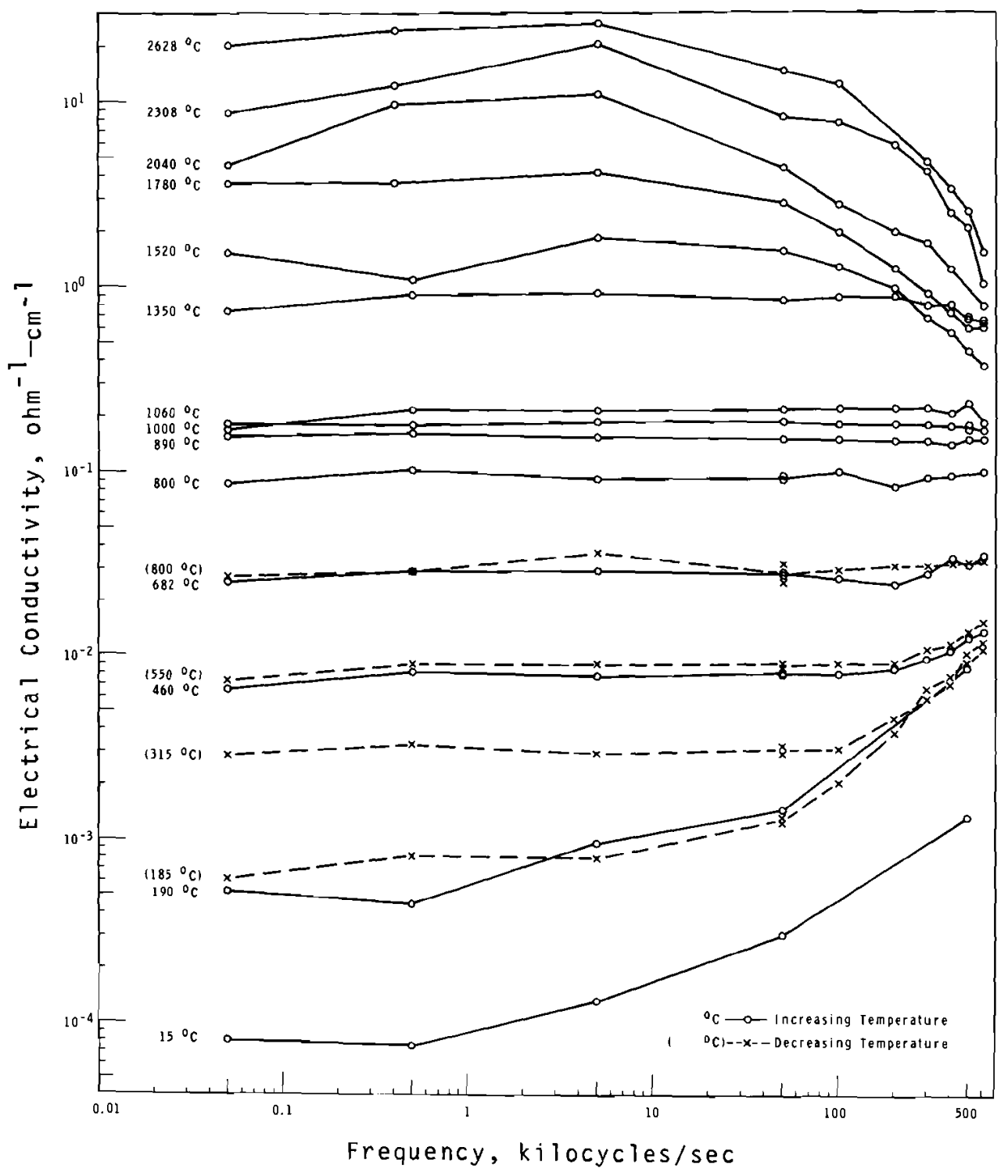

Neg $0661000-5$

EIGURE A-3. Electrical Conductivity of Polycrystaliine Uo, Temperature and Erequency Dependence (Specimen EC-P3A) 
APPENDIX B

ELECTRICAL CONDUCTIVITY OF UO 2

ac AND dc DATA

SPECIMEN B-40-A (Alternating Current)

Run Number 3

$\begin{array}{cc}\begin{array}{c}\text { Temperature, } \\ { }_{\mathrm{K}}\end{array} & \begin{array}{c}\text { Conductivity } \\ \text { ohm-1-cm-1 }\end{array} \\ 1293 & 0.19 \\ 1423 & 0.32 \\ 1543 & 0.60 \\ 1656 & 1.10 \\ 1757 & 1.80 \\ 1833 & 2.40 \\ 1673 & 1.30 \\ 1474 & 0.44 \\ 1273 & 0.20 \\ 1073 & 0.14 \\ 878 & 0.090 \\ 776 & 0.068 \\ 478 & 0.013\end{array}$

Run Number 4

\begin{tabular}{cc}
$\begin{array}{c}\text { Temperature, } \\
{ }_{\mathrm{K}}\end{array}$ & $\begin{array}{c}\text { Rumber } \\
\text { Conductivity } \\
\text { ohm-1-cm-1 }\end{array}$ \\
\hline 1066 & 0.14 \\
1221 & 0.17 \\
1438 & 0.35 \\
1631 & 0.96 \\
1753 & 1.70 \\
1871 & 2.60 \\
2118 & 6.00 \\
2348 & 12.0 \\
2543 & 21.0 \\
2648 & 25.0 \\
2483 & 18.0 \\
2033 & 5.8 \\
1473 & 0.42 \\
1198 & 0.15
\end{tabular}

SPECIMEN B-40-A (Direct Current)

Run Number 1

\begin{tabular}{cc}
$\begin{array}{c}\text { Temperature, } \\
{ }_{\mathrm{K}}\end{array}$ & $\begin{array}{c}\text { Rumber } 1 \\
\text { Conductivity, } \\
\text { ohm-1-cm-1 }\end{array}$ \\
\cline { 2 - 2 } 654 & 0.0401 \\
658 & 0.0374 \\
788 & 0.0710 \\
825 & 0.0811 \\
852 & 0.0887 \\
878 & 0.0903 \\
883 & 0.0942 \\
989 & 0.125 \\
1011 & 0.129 \\
1031 & 0.131 \\
1031 & 0.136 \\
1121 & 0.158 \\
1128 & 0.159 \\
1111 & 0.154 \\
1112 & 0.154 \\
1130 & 0.158 \\
1127 & 0.159 \\
1126 & 0.158 \\
1137 & 0.162 \\
1138 & 0.162 \\
1128 & 0.160 \\
1144 & 0.163
\end{tabular}


Run Number 2

\begin{tabular}{|c|c|}
\hline Temperature, & $\begin{array}{l}\text { Conductivity, } \\
\text { ohm }-1-\mathrm{cm}^{-1}\end{array}$ \\
\hline 1114 & 0.154 \\
\hline 1120 & 0.147 \\
\hline 1116 & 0.156 \\
\hline 1114 & 0.155 \\
\hline 1114 & 0.153 \\
\hline 1068 & 0.142 \\
\hline 1068 & 0.143 \\
\hline 1002 & 0.132 \\
\hline 1000 & 0.133 \\
\hline 972 & 0.120 \\
\hline 960 & 0.122 \\
\hline 897 & 0.0985 \\
\hline 885 & 0.0966 \\
\hline 771 & 0.0643 \\
\hline 778 & 0.0657 \\
\hline 702 & 0.0477 \\
\hline 688 & 0.0436 \\
\hline 613 & 0.0339 \\
\hline 570 & 0.0300 \\
\hline 538 & 0.0226 \\
\hline 523 & 0.0210 \\
\hline 453 & 0.0127 \\
\hline 444 & 0.0113 \\
\hline 410 & 0.0080 \\
\hline 399 & 0.0070 \\
\hline 363 & 0.0042 \\
\hline 358 & 0.0037 \\
\hline 342 & 0.0027 \\
\hline 332 & 0.0024 \\
\hline 318 & 0.0017 \\
\hline 312 & 0.0016 \\
\hline
\end{tabular}

Run Number 3

\begin{tabular}{cc}
$\begin{array}{c}\text { Temperature, } \\
{ }^{\circ} \mathrm{K}\end{array}$ & $\begin{array}{c}\text { Conductivity } \\
\text { ohm-1-cm-1 }\end{array}$ \\
\cline { 2 - 2 } 1143 & 0.1464 \\
1136 & 0.1450 \\
1130 & 0.1461 \\
1273 & 0.1871 \\
1268 & 0.1880 \\
1273 & 0.1876 \\
1480 & 0.4477 \\
1473 & 0.4249 \\
1473 & 0.4267 \\
1673 & 1.223 \\
1673 & 1.201 \\
1673 & 1.223 \\
1873 & 3.114 \\
1880 & 3.095 \\
1876 & 3.095 \\
1923 & 3.756 \\
1923 & 3.721 \\
1929 & 3.721 \\
1773 & 1.866 \\
1773 & 1.832 \\
1773 & 1.823 \\
1573 & 0.721 \\
1573 & 0.721 \\
1575 & 0.719 \\
1373 & 0.274 \\
1373 & 0.276 \\
1373 & 0.279 \\
1173 & 0.165 \\
1173 & 0.163 \\
1173 & 0.164 \\
1173 & 0.168 \\
973 & 0.120 \\
973 & 0.117 \\
973 & 0.119 \\
773 & 0.6686 \\
777 & 0.0683 \\
773 & 0.0674 \\
&
\end{tabular}




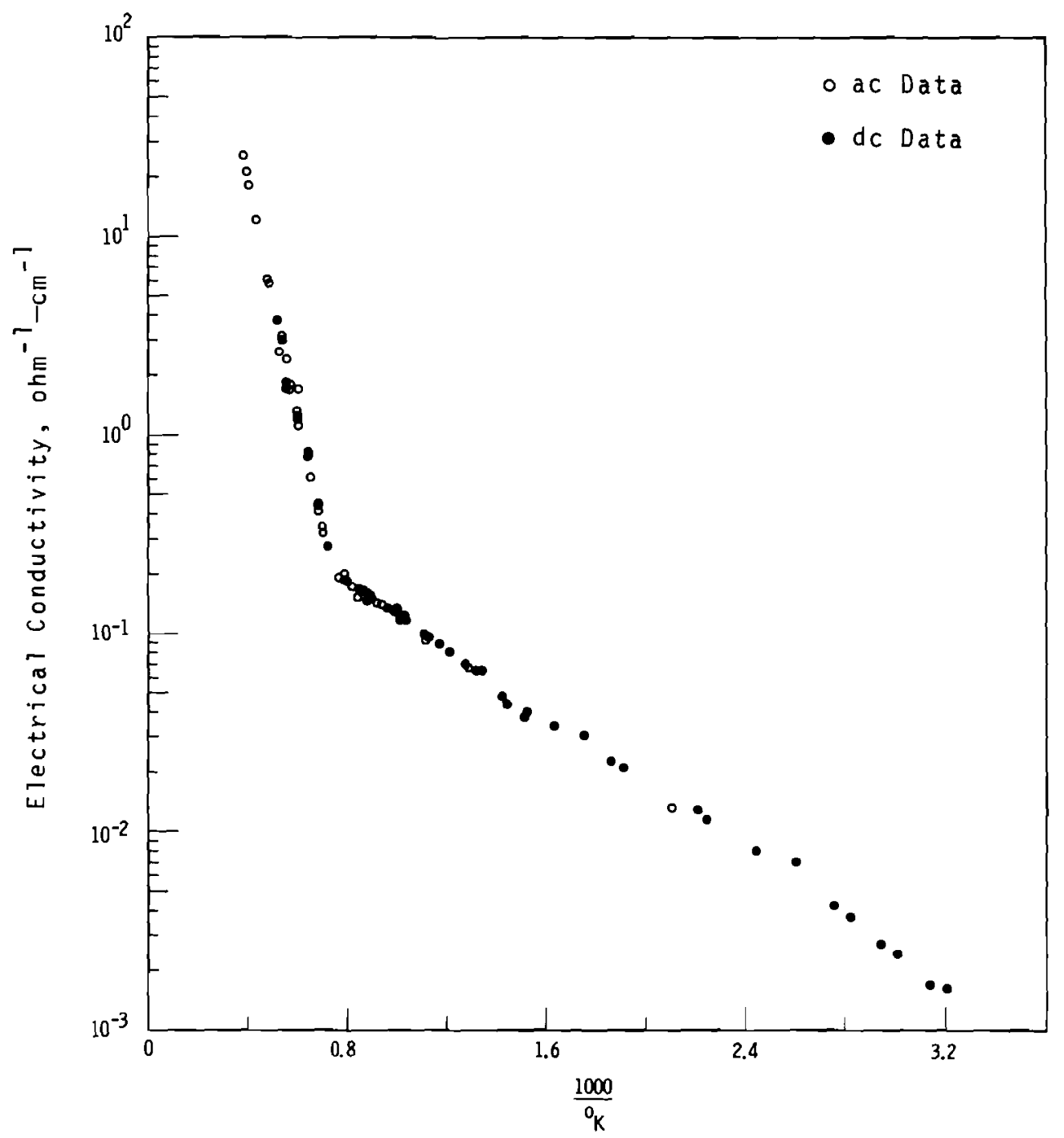

Neg $0671421-4$

FIGURE B-1. Electrical Conductivity of Single Crystal UOZ (B-40-A) Comparing ac and äc Data 
SPECIMEN EC-PIA (Direct Current)

\begin{tabular}{|c|c|}
\hline \multicolumn{2}{|c|}{ Run Number 1} \\
\hline $\begin{array}{c}\text { Temperature, } \\
{ }_{\mathrm{O}} \mathrm{K}\end{array}$ & $\begin{array}{l}\text { Conductivity, } \\
\text { ohm }^{-1}{ }_{-\mathrm{cm}^{-1}}\end{array}$ \\
\hline 1048 & 0.209 \\
\hline 1073 & 0.201 \\
\hline 1120 & 0.218 \\
\hline 1173 & 0.275 \\
\hline 1205 & 0.298 \\
\hline 1267 & 0.328 \\
\hline 1314 & 0.362 \\
\hline 1363 & 0.429 \\
\hline 1433 & 0.452 \\
\hline 1494 & 0.627 \\
\hline 1573 & 0.809 \\
\hline 1673 & 1.15 \\
\hline 1857 & 2.23 \\
\hline 2013 & 3.65 \\
\hline 2158 & 7.04 \\
\hline 2276 & 8.73 \\
\hline 2394 & 12.4 \\
\hline 2483 & 18.2 \\
\hline 2477 & 14.9 \\
\hline 2441 & 16.2 \\
\hline 2317 & 9.38 \\
\hline 2152 & 5.75 \\
\hline 1845 & 2.47 \\
\hline 1633 & 1.30 \\
\hline
\end{tabular}

SPECIMEN EC-PIA (Alternating Current)

Run Number 3

$\begin{array}{cc}\begin{array}{c}\text { Temperature, } \\ { }_{\mathrm{K}}\end{array} & \begin{array}{c}\text { Conductivity, } \\ \text { ohm }^{-1} \mathrm{~cm}^{-1}\end{array} \\ 293 & 0.0016 \\ 483 & 0.024 \\ 778 & 0.16 \\ 1058 & 0.44 \\ 1138 & 0.60 \\ 1273 & 0.67 \\ 1178 & 0.50 \\ 943 & 0.16 \\ 768 & 0.023 \\ 298 & 0.0025\end{array}$

Run Number 4

$\begin{array}{cc}\begin{array}{c}\text { Temperature, } \\ { }^{\circ} \mathrm{K}\end{array} & \begin{array}{c}\text { Conductivity, } \\ \text { ohm }^{-1} \mathrm{~cm}^{-1}\end{array} \\ 1118 & 0.50 \\ 1181 & 0.58 \\ 1445 & 0.91 \\ 1648 & 1.70 \\ 1928 & 4.40 \\ 2133 & 8.00 \\ 2488 & 13.0\end{array}$




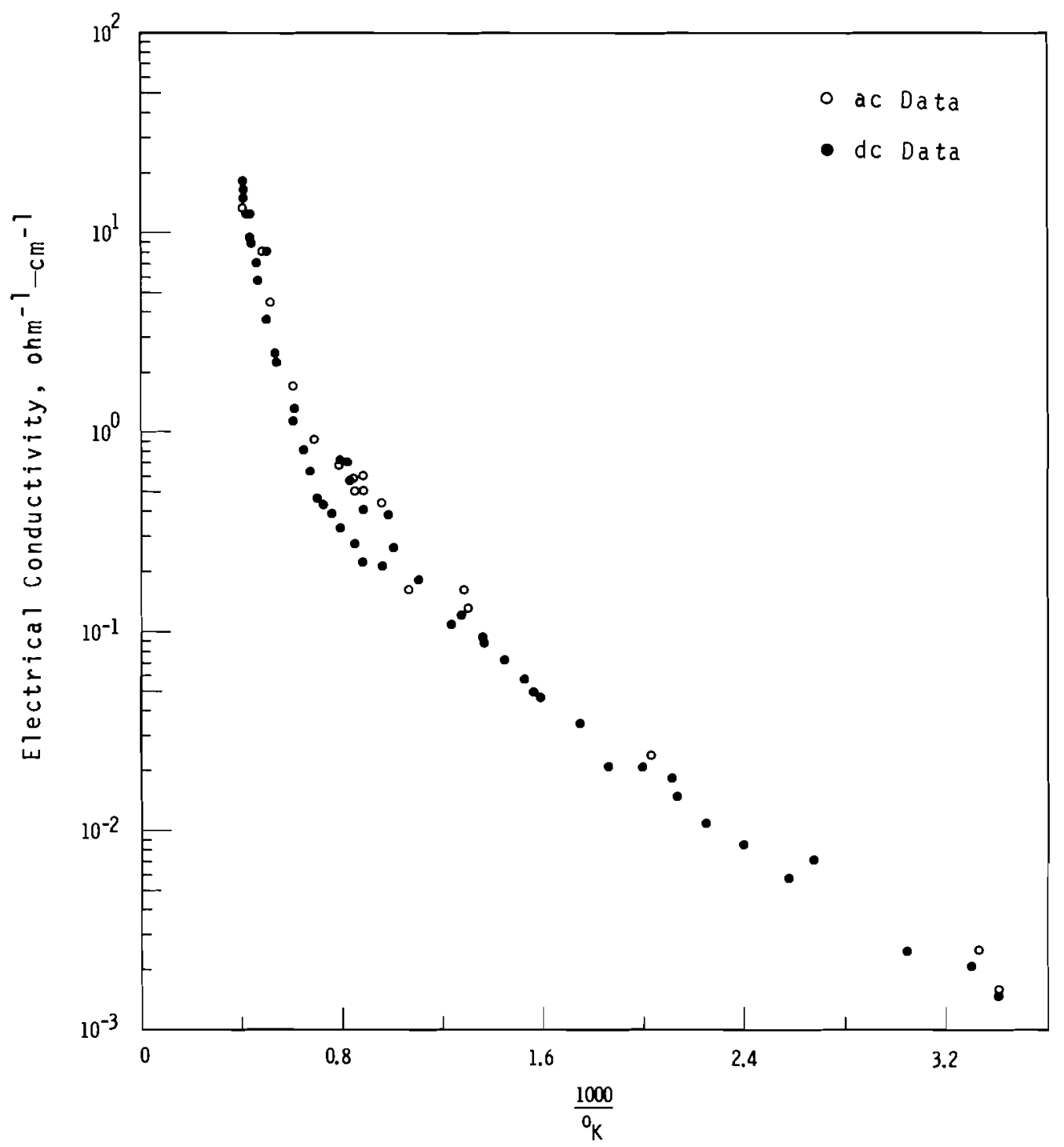

Neg $0671421-2$

FIGURE B-2. Electrical Conductivity 
Run Number 1

$\begin{array}{cc}\begin{array}{c}\text { Temperature, } \\ { }_{\mathrm{K}}\end{array} & \begin{array}{c}\text { Conductivity, } \\ \text { ohm-1-cm-1 }\end{array} \\ 1268 & 0.177 \\ 1278 & 0.182 \\ 1283 & 0.183 \\ 1273 & 0.174 \\ 1273 & 0.179 \\ 1273 & 0.199 \\ 1273 & 0.185 \\ 1273 & 0.199 \\ 1273 & 0.107 \\ 1273 & 0.187 \\ 1223 & 0.173 \\ 1113 & 0.151 \\ 1843 & 0.0904 \\ 803 & 0.0839 \\ 693 & 0.0530 \\ 628 & 0.0426 \\ 563 & 0.0275 \\ 518 & 0.0186 \\ 423 & 0.00902\end{array}$

Run Number 2

\begin{tabular}{cc}
$\begin{array}{c}\text { Temperature, } \\
{ }_{\mathrm{K}}\end{array}$ & $\begin{array}{c}\text { Conductivity, } \\
\text { ohm }^{-1} \mathrm{~cm}^{-1}\end{array}$ \\
\cline { 2 - 2 } 1163 & 0.158 \\
1333 & 0.214 \\
1623 & 0.903 \\
1793 & 1.47 \\
2053 & 3.66 \\
2313 & 17.36 \\
2581 & 14.37 \\
2901 & 21.31 \\
3178 & 30.11 \\
2793 & 23.00 \\
& \\
&
\end{tabular}

SPECIMEN B-38-C (Direct Current)

Run Number 1

$\begin{array}{cc}\begin{array}{c}\text { Temperature, } \\ { }_{\mathrm{K}}\end{array} & \begin{array}{c}\text { Conductivity, } \\ \text { ohm }^{-1}-\mathrm{cm}^{-1}\end{array} \\ 293 & 0.00136 \\ 303 & 0.00183 \\ 305 & 0.00211 \\ 335 & 0.00564 \\ 335 & 0.00612 \\ 520 & 0.0240 \\ 520 & 0.0241 \\ 598 & 0.0408 \\ 598 & 0.0445 \\ 603 & 0.0444 \\ 696 & 0.0625 \\ 783 & 0.0839\end{array}$

Run Number 2

\begin{tabular}{|c|c|}
\hline $\begin{array}{c}\text { Temperature, } \\
{ }^{\circ} \mathrm{K} \\
\end{array}$ & $\begin{array}{l}\text { Conductivity, } \\
\mathrm{ohm}^{-1}-\mathrm{cm}^{-1}\end{array}$ \\
\hline 796 & 0.0790 \\
\hline 880 & 0.0926 \\
\hline 937 & 0.101 \\
\hline 953 & 0.107 \\
\hline 1139 & 0.185 \\
\hline 1208 & 0.159 \\
\hline 1323 & 0.239 \\
\hline 1466 & 0.494 \\
\hline 1523 & 0.849 \\
\hline 1674 & 1.38 \\
\hline 1748 & 1.97 \\
\hline 1817 & 2.61 \\
\hline 1817 & 2.67 \\
\hline 1822 & 2.79 \\
\hline
\end{tabular}




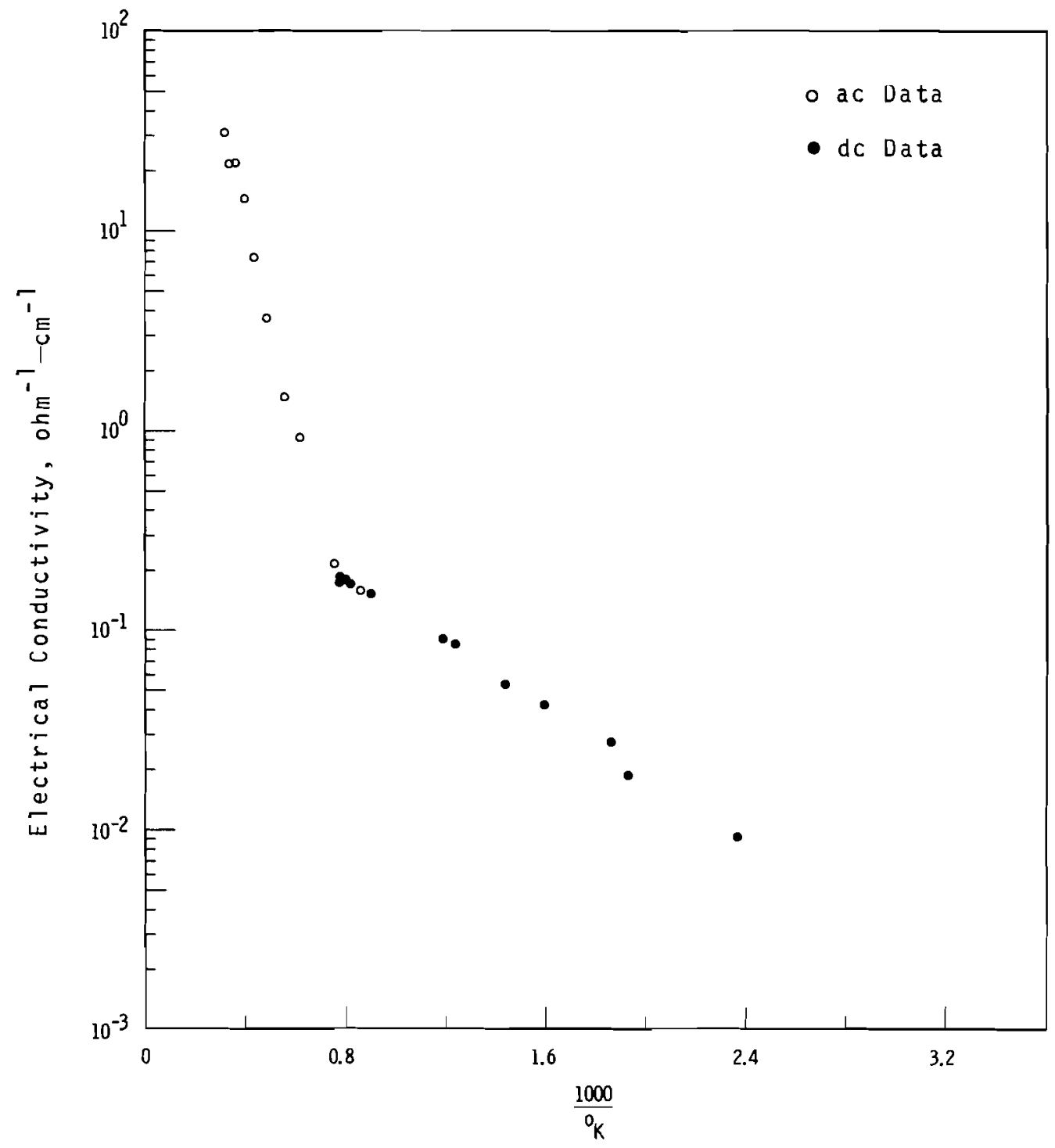

Neg $0671421-1$

FIGURE B-3. Electrical Conductivity of Polycrystalline UO 2 (EC-P3A)

Comparing ac and de Data 
Run Number 3

$\begin{array}{cc}\begin{array}{c}\text { Temperature, } \\ { }^{K}\end{array} & \begin{array}{c}\text { Conductivity, } \\ \text { ohm-1 - cm }-1\end{array} \\ 1549 & 0.593 \\ 1623 & 0.817 \\ 1708 & 0.839 \\ 1782 & 1.31 \\ 1877 & 1.86 \\ 1965 & 2.73 \\ 2076 & 3.63 \\ 2256 & 5.42 \\ 2851 & 7.77 \\ 2134 & 3.42 \\ 2213 & 6.17 \\ 2434 & 8.19 \\ 2434 & 11.8 \\ 2434 & 14.3 \\ 2555 & 16.9 \\ 2673 & 22.8 \\ 2075 & 27.2 \\ 2075 & 5.70 \\ & 5.35\end{array}$

Run Number 4

\begin{tabular}{cc}
\hline Temperature, & $\begin{array}{c}\text { Conductiv } \\
{ }^{\text {ohm }}{ }^{-1}-\mathrm{cm}\end{array}$ \\
1519 & 0.486 \\
1519 & 0.506 \\
1672 & 1.20 \\
1669 & 1.13 \\
1885 & 2.51 \\
2145 & 7.24 \\
2332 & 9.74 \\
2296 & 0.8 \\
2127 & 6.37 \\
1971 & 3.50 \\
1733 & 1.53
\end{tabular}

Run Number 5

\begin{tabular}{cc}
\hline $\begin{array}{c}\text { Temperature, } \\
{ }^{\circ} \mathrm{K}\end{array}$ & $\begin{array}{c}\text { Conductivity, } \\
\text { ohm-1-cm-1 }\end{array}$ \\
1873 & 2.77 \\
2093 & 5.65 \\
2148 & 6.51 \\
2213 & 8.36 \\
2368 & 13.4 \\
2373 & 13.6 \\
2569 & 18.2 \\
2713 & 27.5 \\
2713 & 32.1 \\
2011 & 5.81
\end{tabular}

SPECIMEN B-38-C (A1ternating Current)

Run Number 1

$\begin{array}{cc}\begin{array}{c}\text { Temperature, } \\ { }_{\mathrm{K}}\end{array} & \begin{array}{c}\text { Conductivity, } \\ \text { ohm-1-cm-1 }\end{array} \\ 293 & 0.00096 \\ 293 & 0.00100 \\ 293 & 0.00102 \\ 303 & 0.00143 \\ 305 & 0.00154 \\ 329 & 0.0309 \\ 468 & 0.0128 \\ 520 & 0.0228 \\ 520 & 0.0416 \\ 598 & \\ 598 & 0.0431 \\ 603 & 0.0627 \\ 696 & 0.0746 \\ 783 & \end{array}$

Run Number 2

\begin{tabular}{cc}
$\begin{array}{c}\text { Temperature, } \\
{ }^{\circ} \mathrm{K}\end{array}$ & $\begin{array}{r}\text { Conductivity, } \\
\text { ohm-1-cm-1 }\end{array}$ \\
\hline 796 & 0.0771 \\
880 & 0.0920 \\
923 & 0.0983 \\
937 & 0.100 \\
953 & 0.102 \\
1139 & 0.131 \\
1208 & 0.155 \\
1323 & 0.240 \\
1453 & 0.476 \\
1523 & 0.815 \\
1674 & 1.319 \\
1748 & 1.823 \\
1793 & 1.892 \\
1817 & 2.388 \\
1825 & 2.79
\end{tabular}


Run Number 3

\begin{tabular}{|c|c|}
\hline $\begin{array}{c}\text { Temperature, } \\
{ }_{\mathrm{K}}\end{array}$ & $\begin{array}{l}\text { Conductivity, } \\
\mathrm{ohm}^{-1}-\mathrm{cm}^{-1}\end{array}$ \\
\hline 1479 & 0.577 \\
\hline 1549 & 0.567 \\
\hline 1623 & 0.815 \\
\hline 1623 & 0.819 \\
\hline 1688 & 1.20 \\
\hline 1708 & 1.25 \\
\hline 1782 & 1.76 \\
\hline 1788 & 1.81 \\
\hline 1869 & 2.52 \\
\hline 1877 & 2.60 \\
\hline 1877 & 2.67 \\
\hline 1965 & 3.49 \\
\hline 1965 & 3.04 \\
\hline 2071 & 4.56 \\
\hline 2074 & 4.78 \\
\hline 2190 & 6.89 \\
\hline 1851 & 3.38 \\
\hline 2134 & 6.21 \\
\hline 2213 & 8.02 \\
\hline 2434 & 11.51 \\
\hline 2434 & 15.2 \\
\hline \multirow[t]{2}{*}{2434} & 17.3 \\
\hline & 15.9 \\
\hline 2555 & 20.1 \\
\hline 2809 & 36.5 \\
\hline 2075 & 5.73 \\
\hline 2075 & 5.33 \\
\hline 1910 & 5.23 \\
\hline 1868 & 2.82 \\
\hline 1841 & 2.55 \\
\hline 1735 & 1.70 \\
\hline 1701 & 1.40 \\
\hline 1674 & 1.29 \\
\hline 1628 & 1.03 \\
\hline 1588 & 0.836 \\
\hline 1558 & 0.701 \\
\hline 1521 & 0.535 \\
\hline 1483 & 0.436 \\
\hline 1431 & 0.369 \\
\hline 1423 & 0.313 \\
\hline 1388 & 0.271 \\
\hline 1318 & 0.222 \\
\hline 1273 & 0.1985 \\
\hline
\end{tabular}

Run Number 4

\begin{tabular}{cc}
\hline $\begin{array}{c}\text { Temperature, } \\
{ }_{K}\end{array}$ & $\begin{array}{c}\text { Conductivity, } \\
\text { ohm }-1-\mathrm{cm}^{-1}\end{array}$ \\
1519 & 0.486 \\
1591 & 0.490 \\
1672 & 1.12 \\
1669 & 1.10 \\
1858 & 2.11 \\
1858 & 2.40 \\
2145 & 6.33 \\
2274 & 8.53 \\
2332 & 9.24 \\
2332 & 11.3 \\
2296 & 10.2 \\
2321 & 3.4 \\
2321 & 15.7 \\
2603 & 19.86 \\
2244 & 9.67 \\
2127 & 6.04 \\
1971 & 3.37 \\
1733 & 1.47 \\
1626 & 0.918
\end{tabular}

Run Number 5

\begin{tabular}{cc}
$\begin{array}{c}\text { Temperature, } \\
{ }^{K} \mathrm{~K}\end{array}$ & $\begin{array}{c}\text { Conductivity, } \\
\text { ohm }^{-1}-\mathrm{cm}^{-1}\end{array}$ \\
\hline 1873 & 2.80 \\
2093 & 5.41 \\
2148 & 6.56 \\
2213 & 8.12 \\
2368 & 12.3 \\
2368 & 12.7 \\
2373 & 12.7 \\
2569 & 18.6 \\
2569 & 23.7 \\
2686 & 22.9 \\
2555 & 19.6 \\
2320 & 12.8 \\
2236 & 9.12 \\
2011 & 5.76 \\
2823 & 29.4 \\
2838 & 31.7 \\
2838 & 32.5 \\
2908 & 41.5 \\
2973 & 41.6 \\
2105 & 6.10 \\
2073 & 5.75
\end{tabular}




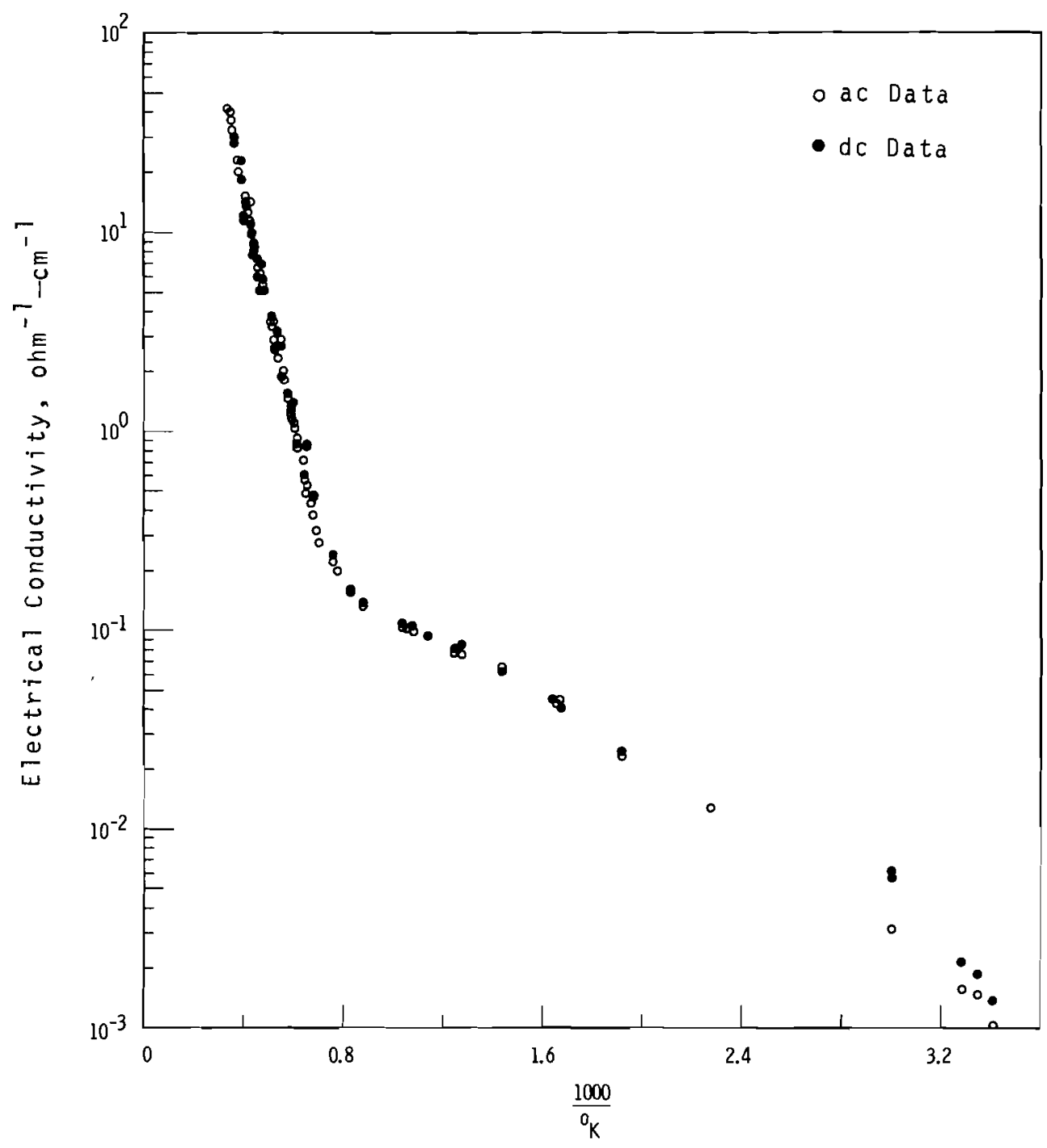

$B-4 \quad$ Neg $0671421-3$

FIGURE B-4. Electrical Conductivity of Polycrystalline $\mathrm{UO}_{2}(B-38-C)$ Comparing ac and de Data 
No. of

\section{Copies}

268 AEC Division of Technical Information Extension

2 AEC, RDT Site Representative $\overline{\mathrm{PNL}}$

P. G. Holsted

3 AEC Richland Operations Office

C. L. Robinson

R. K. Sharp

Technical Information Library

$1 \quad$ ALKEM

7501 Leopoldshafen

Karlsruhe, Germany

W. Stol1

8 Argonne National Laboratory

C. H. Bean

R. K. Edwards

J. H. Handwerk

J. H. Kittel

R. Macherey

D. Readey

J. F. Schumar

R. J. Thorn

1 Associazione Euratom-CNEN Per I

Reattori Veloci

Via Mazzini 2

Bologna, Italy

F. Pierantoni

5 Atomic Energy Commission,

Washington

Division of Reactor Development

R. Grube

J. M. Morrisey

J. M. Simmons

W. R. Voigt

M. J. Whitman

2 Atomic Energy of Canada Limited Chemistry and Metallurgy Branch Fuels Development Branch Chalk River, Ontario, Canada

J.A. L. Robertson

M. F. Notley
No. of

Copies

5 Atomic Energy Research Establishment

United Kingdom Atomic Energy

Authority

Harwe11, Didcot, Berks, England

P. Murray (3)

L. E. Russel1

J. Williams

1 Atomics International

B. R. Hayward

2 Atomic Power Development Associates, Inc.

W. H. Jens

A. A. Shoudy

6 Battelle Memorial Institute

H. Deem

J. J. Duga

W. F. Heenan

D. L. Keller

S. W. Porembka

1 Brookhaven National Laboratory D. H. Gurinsky

1 Centre d'Etudes Nucleaires de Cadarache

Poite Postale No. 1

Saint-Paul-Lez-Durance, France

Dr. B. Defreyn

1 C.E.N. - Belgonucleaire Mo1, Belgium

J. M. Leblanc

2 Center Research Laboratory

Tokyo Shibaura Electroc Co., Ltd. Komukai, Kawasaki, Japan

T. Nishijima

T. Kawada

1 Conute National pour l'energie Nucleare

Casaccia, Centre

Rome, Italy

S. Moretti 
No. of

Copies

2 Transuranium Institute (Euratom) Karlsstrasse 42-44 Karlsruhe, Germany

H. M. Mattys

H. C. Schmidt

5 Union Carbide Corporation (ORNL)

R. M. Carroll

T. F. Connally

D. E. McEl roy

J. L. Scott

W. C. Thurber

1 United Aircraft Corporation Research Laboratory

East Hartford, Connecticut

G. H. McLafferty

1 University of Arizona

Nuclear Engineering Dept.

Tucson, Arizona

Monte V. Davis

1 University of California, Livermore

Dr. James Hadley

1 University of Michigan

College of Engineering

Ann Arbor, Michigan

W. Kerr

3 U.S. Atomic Energy Commission Brussels, Belgium

C. F. Schank

2 Westinghouse Bettis Atomic Power Laboratory

J. Be11e

$B$. Lustman
No. of

Copies

4 Westinghouse Electric Corporation

Robert Allio

A. A. Bishop

A. Boltax

N. R. Nelson

1 Wright Air Development Center AF Materials Laboratory Wright-Patterson AFB, Dayton, Ohio

S. W. Bradstreet

58 Battelle-Northwest

R. J. Baker

J. L. Bates (29)

T. D. Chikalla

J. A. Christensen

P. D. Cohn

G. M. Dalen

J. L. Daniel

D. R. de Halas

K. Drumheller

E. A. Evans

P. L. Farnsworth

R. L. Gibby

W. L. Hampson

C. E. McNeilly

R. P. Nelson

R. E. Nightingale

W. E. Roake

R. K. Robinson

R. C. Smith

H. A. Taylor

G. L. Tingey

E. T. Weber

H. H. Yoshikawa

Technical Publications (2)

Technical Information Files 


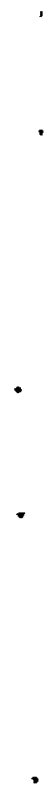

, 